\title{
Migration of Silver and Copper Nanoparticles from Food Coating
}

\author{
Hamed Ahari *D and Leila Khoshboui Lahijani \\ Department of Food Science and Technology, Science and Research Branch, Islamic Azad University, \\ Tehran 14177-55469, Iran; leila.khoshbou@gmail.com \\ * Correspondence: dr.h.ahari@gmail.com
}

check for

updates

Citation: Ahari, H.; Lahijani, L.K. Migration of Silver and Copper Nanoparticles from Food Coating. Coatings 2021, 11, 380. https:// doi.org/10.3390/coatings11040380

Academic Editor: Maria Jose Fabra

Received: 23 February 2021

Accepted: 17 March 2021

Published: 26 March 2021

Publisher's Note: MDPI stays neutral with regard to jurisdictional claims in published maps and institutional affiliations.

Copyright: (c) 2021 by the authors. Licensee MDPI, Basel, Switzerland. This article is an open access article distributed under the terms and conditions of the Creative Commons Attribution (CC BY) license (https:// creativecommons.org/licenses/by/ $4.0 /)$.

\begin{abstract}
Packaging containing nanoparticles (NPs) can increase the shelf life of products, but the presence of NPs may hazards human life. In this regard, there are reports regarding the side effect and cytotoxicity of nanoparticles. The main aim of this research was to study the migration of silver and copper nanoparticles from the packaging to the food matrix as well as the assessment techniques. The diffusion and migration of nanoparticles can be analyzed by analytical techniques including atomic absorption, inductively coupled plasma mass spectrometry, inductively coupled plasma atomic emission, and inductively coupled plasma optical emission spectroscopy, as well as X-ray diffraction, spectroscopy, migration, and titration. Inductively coupled plasma-based techniques demonstrated the best results. Reports indicated that studies on the migration of $\mathrm{Ag} / \mathrm{Cu}$ nanoparticles do not agree with each other, but almost all studies agree that the migration of these nanoparticles is higher in acidic environments. There are widespread ambiguities about the mechanism of nanoparticle toxicity, so understanding these nanoparticles and their toxic effects are essential. Nanomaterials that enter the body in a variety of ways can be distributed throughout the body and damage human cells by altering mitochondrial function, producing reactive oxygen, and increasing membrane permeability, leading to toxic effects and chronic disease. Therefore, more research needs to be done on the development of food packaging coatings with consideration given to the main parameters affecting nanoparticles migration.
\end{abstract}

Keywords: food packaging; silver; copper; migration; nanoparticle

\section{Introduction}

Food packaging is at the heart of the modern food industry, and most products are packaged. Good packaging prevents food from being wasted as well as contaminated and ensures that the food maintains its desired quality throughout storage and consumption. Given the importance and key role that packaging plays, often at best, the packaging industry leads to a serious waste of resources and a threat to the environment. However, if the goal of feeding 9 billion people worldwide is to be achieved, the quality and quantity of food packaging must increase significantly [1].

Recently, active antimicrobial packaging has been introduced as an effective technology to prevent the growth of microorganisms in food products. In this type of packaging, while maintaining the quality and sensory properties of food products, it enhances their shelf life and microbial safety during storage. In recent years, a great deal of effort has been put into producing different food coatings with more efficient antimicrobial capabilities, higher mechanical strength, and greater biocompatibility [2].

Regarding the issue above, more effective natural antimicrobial compounds including bacteriocins, bacteriophages, and essential oils from various sources have been recommended rather than synthetic ones. The integration of these agents with the coatings is seen as a novel type of food packaging. Antimicrobial compounds tend to be degraded during incorporation in food processing and storage. In this regard, microencapsulation has 
been introduced as an alternative technique for overcoming this issue [3]. Encapsulation strategies, including core-shell nanofibers, cyclodextrins, nanoemulsions, and liposomes, have been employed to protect antimicrobials from volatilization or degradation while providing a sustained antimicrobial action or a potent controlled release. It was also depicted that encapsulation enhances the stability of compounds from production until consumption $[2,3]$.

As previously mentioned, various compounds can be encapsulated for food packaging purposes. Essential oils [4-6], noble metal such as silver $(\mathrm{Ag})[7,8]$, gold $(\mathrm{Au})[9,10]$, and also metal oxides such as copper oxide $(\mathrm{CuO})[11,12]$, titanium oxide $\left(\mathrm{TiO}_{2}\right)[7,13]$, zinc oxide ( $\mathrm{ZnO})[11,14]$, magnesium oxide $(\mathrm{MgO})[15]$, and so on, are of the well-known components in food packaging systems (FPSs).

In general, nanomaterials are categorized into two groups: organic and inorganic materials. For the first group of materials, metals and oxides of metals as well as clay nanoparticles that are embedded in biocomposite films and nanofibers can be considered [16]. In addition to the common bacteriostatic nanoparticles of silver, some inorganic agents, such as oxidized nanoparticles like $\mathrm{CuO}, \mathrm{ZnO}, \mathrm{TiO}_{2}, \mathrm{MgO}$, and iron (III) oxide $\left(\mathrm{Fe}_{3} \mathrm{O}_{4}\right)$ are of interest due to their resistance to harsh processing conditions and their increased strong inhibition against food pathogens. In the case of other materials such as various clays, they can resist gases and water vapor and improve the mechanical strength of biopolymers [17]. The second group of organic matter includes phenols, halogenated compounds, quaternary ammonium salts, plastic polymers, as well as natural polysaccharides or protein materials such as chitosan, chitin, saddle, and whey proteins that have recently received much attention $[18,19]$.

Nanoparticles (NPs) have the lowest level of toxicity in the life cycle and ecosystem, so using these materials to fight pathogenic microbes can be a good choice. Metal oxide NPs show different antibacterial properties based on the surface-to-volume ratio. Grampositive bacteria are more resistant to metal NPs than gram-negative bacteria, which may be related to the structure of the cell wall [20]. Numerous studies that consider the possible reactions between macromolecules of living organisms and NPs have been carried out. The difference between the negative charge of the microorganism and the positive charge of the NP acts as an absorbent electromagnet between the microbe and the NP, causing the NP to attach to the cell surface, resulting in cell death [21].

Eventually, many of these contacts lead to the oxidation of microbial surface molecules and their rapid death. The ions released from the nanomaterials are likely to react with the thiol (-SH) groups of the surface proteins of bacterial cells. Some of these bacterial cell membrane proteins are responsible for transporting minerals from the wall surface; nanomaterials acting on these proteins cause inactivation and impermeability of the membrane [22]. Disabling membrane permeability eventually causes cell death. Nanomaterials also delay bacterial cell adhesion and biofilm formation, which prevents a group of bacteria from being able to stabilize and multiply [23].

Due to their antibacterial properties, $\mathrm{Ag} / \mathrm{Cu}$ NPs can be loaded in various polymers, either as a coating or film, and can be used in modern food packaging [24]. This prevents microbial spoilage of food with greater efficiency. The methods currently employed to control microbes (adding preservatives) revealed disadvantages such as weak performance and good compatibility of microorganisms with preservatives [25]. Silver nanoparticles (AgNPs) do not react chemically with microorganisms but act as catalysts in their destruction; therefore, microorganisms do not resist them, and the risk of genetic mutations of microorganisms that are due to the direct use of toxins is eliminated. AgNPs that are combined with polymers show their potential in FPSs [26]. In a study, AgNPs were incorporated with nanofibers for antimicrobial food packaging applications of lemon and strawberry. Based on the results, they successfully extended the shelf life by 10 days [27]. It was also reported that the AgNPs exhibited inhibitory effects on two important food pathogens and did not show any toxic effects on colon cells during $24 \mathrm{~h}$ [28]. One study showed that AgNPs embedded in sodium alginate coating employed for packaging Fior 
di Latte cheese could strongly prevent Enterobacteriaceae, Pseudomonas spp. and E. coli growth [29]. There are numerous studies that consider the potent role of AgNPs in food packaging, as reviewed by Marilena Carbone [26].

In addition to AgNPs, copper nanoparticles (CuNPs) is another powerful nanoagent that have been extensively employed in FPSs. One of the main responsibilities of $\mathrm{Cu} / \mathrm{CuO}$ NPs is their antimicrobial activity, which significantly prevents or decreases bacteria, viruses, and fungi growth. The antimicrobial mechanism is similar to that of other NPs, including AgNPs. It was depicted that the addition of CuNPs increases the mechanical properties and thermal stability of carrageenan-based films [30]. Regardless of the inherent antibacterial features in the substrate (film or coating) as food packaging, the addition of $\mathrm{Cu}$ will promote the antibacterial efficiency of the whole system [31].

Loading NPs in FPSs is a significant issue, but the most important issue is how (release rate and mass flow) they are released. As far as we know, there is no comprehensive review regarding the release of these NPs from food packages. In this review, we attempt to discuss the release of $\mathrm{Ag}$ and $\mathrm{Cu}$ NPs from the coating/film and also how they fight against microorganisms.

\section{Nanoparticles in Food Packaging Systems}

The urgency of preventing food-borne diseases has multiplied the need to produce antimicrobial food packaging. In this regard, special packaging is needed to be able to release the active ingredients of the bioside in order to improve the quality of food, have a longer shelf life, and prevent or at least delay spoilage. For these reasons, employing metal/metal oxide NPs (mNPs) in food packaging gave signs of improvement.

NPs can be incorporated with biomaterial via various methods including coating, adsorption, and direct incorporation [32]. Based on these methods, NPs have the chance to be released directly into the food or the environment around them [33]. The side effect of these strategies on human life has been challenging and debatable. Reaching the appropriate dose of mNPs for the highest biocide efficiency while having no hazards for human life is at the top of the list.

\subsection{AgNP-Based Food Packaging Systems}

Among the metals previously discussed, AgNP has been shown to have significant antibacterial effects against a wide range of pathogenic microorganisms, including viruses, bacteria, fungi, and yeasts (Figure 1A) [34-36]. Due to the potential of AgNPs, they can interact strongly with microorganisms and inactivate them so that more restraint can be achieved (Figure 1B) [37-39].

Embedding AgNP in films and coatings is important for active food packaging (AFP) purposes and for decreasing the risk of pathogens. For this purpose, various biological materials (synthesized and natural) are used [37]. There are several studies reporting new films and coating to keep foods for a long time during storage.

According to the previous studies, AgNPs can be incorporated with both degradable and nondegradable biomaterials by which film permeability, product quality, mechanical properties of the coating were improved. For instance, Derong Lin and his colleagues [7] tried to incorporate $\mathrm{TiO}_{2}$ and $\mathrm{Ag}$ NPs with fish gelatin and chitosan film (due to their good film-forming, water locking properties, antibacterial ability, and antioxidant properties) with excellent antibacterial properties for improving shelf life purposes. As the $\mathrm{TiO}_{2}-\mathrm{Ag}$ concentration increased, no significant increase was observed in the film thickness. It is to necessary to note that thickness changes may affect the mechanical properties and barrier properties of the films. $\mathrm{TiO}_{2}-\mathrm{Ag}$ NPs have the chance to interact with amino acids in the matrix, which might be the reason for any thickness changes [40]. They also reported that optimizing NP concentrations is important because high concentrations lead to low aggregation and levels, low antimicrobial properties, and low transparency [41]. Disk diffusion results showed that adding $\mathrm{TiO}_{2}-\mathrm{Ag}$ NPs significantly resulted in the antibacterial performance enhancement of the film against E. coli (gram +), Staphylococcus aureus 
(S. aureus) (gram -), and Botrytis cinerea (molds). In research done by Ahari and his colleagues, AgNP was first synthesized by chemical reduction and then used for embedding in nanocomposites. The final nanocomposites were employed for food packaging purposes to fight against E. coli and S. aureus [42]. In another similar research by them, a similar nanocomposite containing AgNPs was prepared for increasing the shelf life of Huso huso fillet during cold storage [43].

In another study, Muhammad Bilal Khan Niazi et al. [44] developed biodegradable nanocomposite films with the aim of antimicrobial food packaging applications. The films could show acceptable antimicrobial performance against both gram-negative and grampositive bacteria. The intensive antibacterial performance was reported for gram-negative bacteria (Escherichia coli (DH5-alpha)). By the incorporation of AgNPs, the mechanical features were improved and WVTR lowered (Figure 1C). It was found that these films can retain high humidity, which is desirable for fresh fruits and vegetables with high respiration rates. In a similar study, AgNPs along with laponite were embedded in chitosan film for AFP evaluation (litchis). The mechanical, OTR, and water solubility properties of chitosan-based films were improved due to the synergistic effect of laponite and AgNPs. Most importantly, laponite has shown a significant ability to inhibit the release of AgNPs in chitosan-based films, which can overcome the cytotoxic effects of AgNP [45]. Lately, Jie Zhang et al. [46] created a biofilm by poly (butylene adipate-co terephthalate)/titanium dioxide/silver composite via a common solvent casting method for AFP purposes (cherry tomato). These films depict strong antibacterial activity against E. coli and $S$. aureus. $\mathrm{TiO}_{2}-\mathrm{NP}$ has been shown to prove its potential in reinforcing polymeric matrices in food packaging applications due to its nontoxicity, low cost, and biocompatibility [47]. It was also shown that the antibacterial efficiency of $\mathrm{TiO}_{2}$ is noticeably increased because of the synergistic antibacterial effects of AgNPs and $\mathrm{TiO}_{2}$ [48].
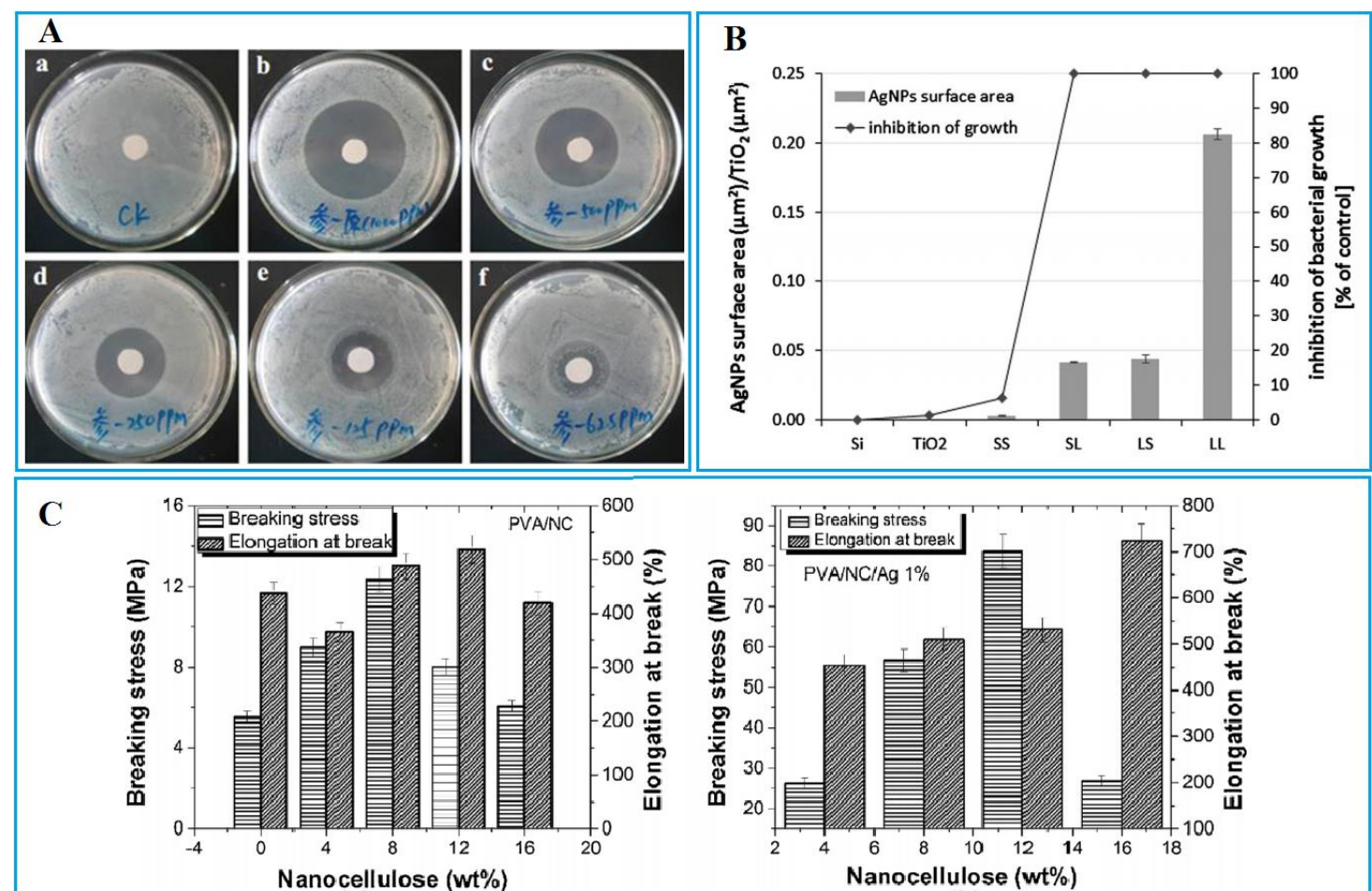

(a)

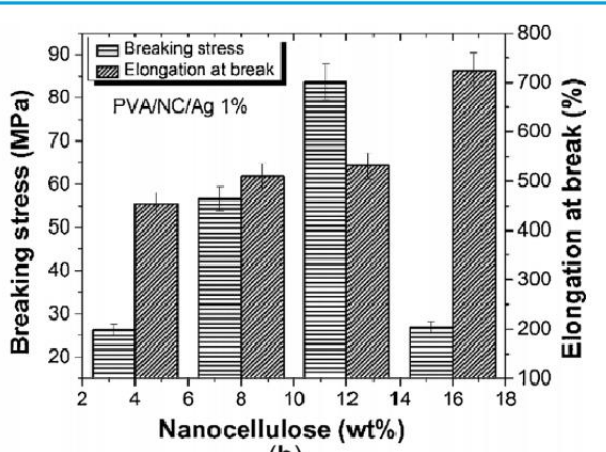

(b)

Figure 1. (A) Disk diffusion test of AgNPs against E. coli (a: Control; b: 1000 ppm; c: 500 ppm; d: 250 ppm; e: 125 ppm; f: 62.5 ppm). Reprinted with permission from [49]. Copyright 2020 Ingenta. (B) The surface area of AgNPs showed an association with growth inhibition of $S$. aureus after $24 \mathrm{~h}$ of incubation on $\mathrm{TiO}_{2}$ coatings with AgNP. Reprinted with permission from [50]. Copyright 2014 The Royal Society of Chemistry. (C) Elongation and breaking stress at the break of (i: neat PVA, PVA/NC) and (ii: PVA/NC 4\%/Ag 1\%). Reprinted with permission from [44]. Copyright 2018 Elsevier. 


\subsection{CuNP-Based Food Packaging Systems}

In addition to bacteria, copper composite has been also effective against other pathogens. It can fight fungi, viruses, and other food poisoning bacteria, including listeria and salmonella, and MRSA, a bacterium that is especially difficult to treat with antibiotics, and there is a belief that NPs have the potential to be effective against a whole range of foodborne illnesses. Researchers have employed CuNPs as an antimicrobial agent due to their simple synthesizes, lower price, and their nutraceutical properties compared to AgNPs in some cases. Several types of research have been carried out on studying the antimicrobial properties of CuNPs using various percentages and also different matrixes named HDPE (high-density polyethylene) (Figure 2A), LDPE (low-density polyethylene) (Figure 2B), cellulose, etc. [12,51,52]. CuNP-based AFP can also affect the mechanical [53], thermal [54], gas barrier properties as well as the UV inhibition feature [55].

However, it has been shown that copper can also be toxic, especially at the nanometer dimension. It is generally known that low concentrations of copper are essential as vital cofactors for metalloproteins and enzymes in all living organisms, including bacteria, whereas at higher concentrations it can result in a toxic effect by essential ions displacement. As a result, it blocks the functional groups of proteins, inactivates enzymes, and produces hydroperoxide free radicals [56]. Remarkably, since the size of copper is at the nanoscale, the ratio of surface atoms is enhanced, which increases the reaction and turns them into highly reactive sites, resulting in severe antimicrobial behavior and toxicity.

Permission to use nanocomposites in food packaging may depend on its performance in migration tests, as the migration of NPs from the FPS and nanocomposite system to food and beverages increases the likelihood of endangering the health of the customer [58]. Further research and assessment need to be conducted to explore their potential toxicity.

Many studies have reported that the application of NPs in food packaging may cause NP migration into foodstuff that, in turn, results in toxicity [55]. According to the literature, CuNPs can be significantly incorporated with the polymeric matrix, and due to their high surface-to-volume ratio, reactivity, and good release properties, they exert their biotechnological effects [59].

Komeilynia and his colleagues evaluated CuNPs-based cotton-nylon nanocomposites by employing the method of chemical reduction synthesizing on S. aureus. Although the SEM and TEM results showed that the average size of the synthesized NPs was $85 \mathrm{~nm}$, according to the results, the addition of CuNPs could reduce the population of S. aureus. In addition, the physicochemical properties of the prepared nanocomposite were significantly improved compared to the control samples (Figure 2C) [57]. In another study, it was proven that when CuNPs are added into films, they can inhibit the survival of microorganisms [51]. 

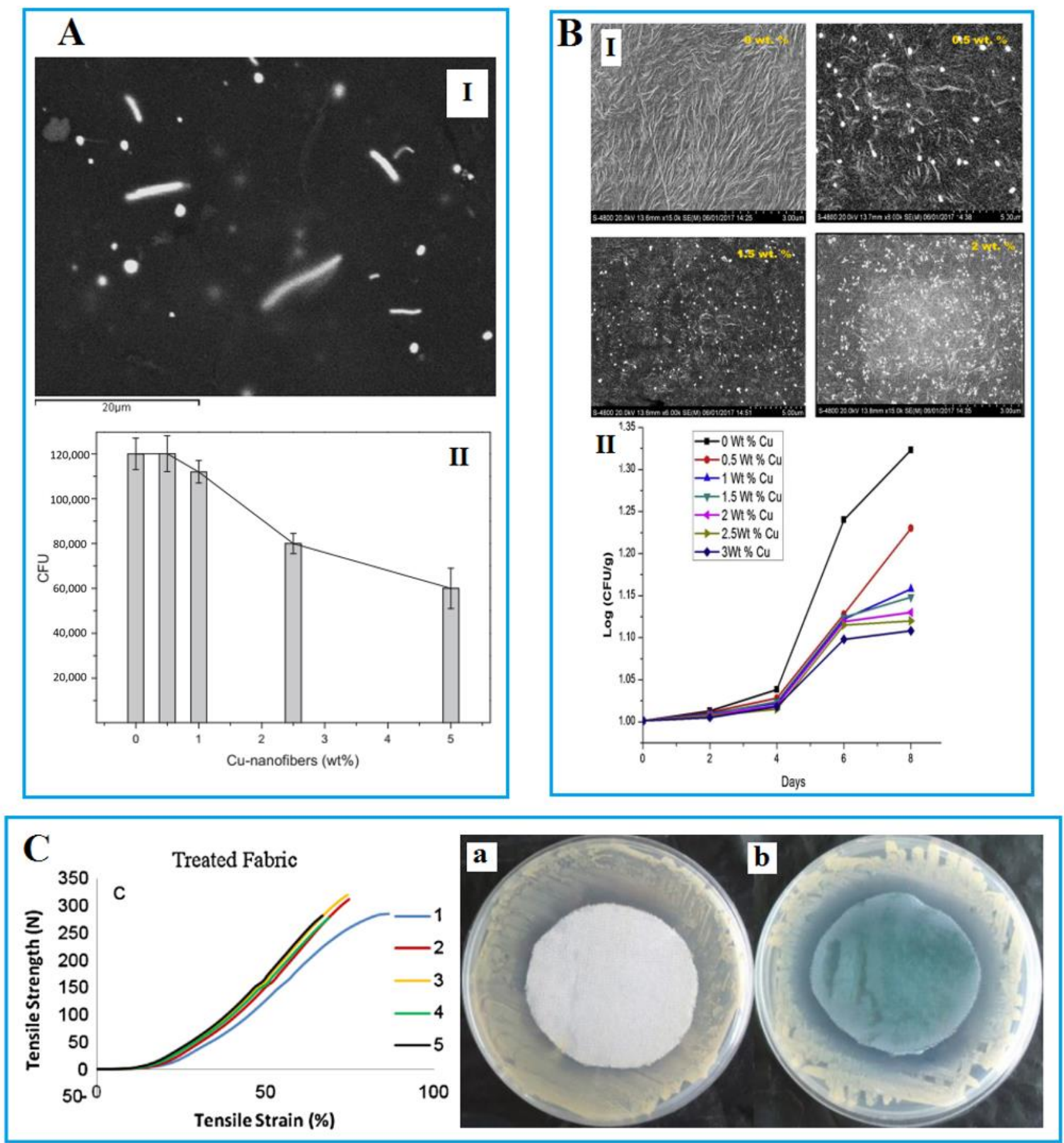

Figure 2. (A) I: SEM images of high-density polyethylene (HDPE)/Cu-nanofiber nanocomposites containing 2.5 wt.\% $\mathrm{Cu}$-nanofibers; II: The effect of $\mathrm{Cu}$ content of HDPE/Cu-nanofiber nanocomposites on the growth of bacterial colonies forming units (CFU). Reprinted with permission from [51]. Copyright 2013 Elsevier. (B) I: Pure low-density polyethylene (LDPE) and LDPE/Cu nanocomposite films ( $0 \mathrm{wt} . \%$ scale bar $=3 \mu \mathrm{m} ; 0.5 \mathrm{wt} . \%$ scale bar = $5 \mu \mathrm{m} ; 1.5 \mathrm{wt} . \%$ scale bar = $5 \mu \mathrm{m}$; 2.0 wt. $\%$ scale bar $=3 \mu \mathrm{m} ; 2.5$ wt. $\%$ scale bar $=5 \mu \mathrm{m} ; 3$ wt. $\%$ scale bar $=5 \mu \mathrm{m}$ ); II: The effect of various content of CuNPs on antibacterial activity assay of LDPE/Cu nanocomposite during incubation time of $24 \mathrm{~h}$. Reprinted with permission [12]. Copyright 2018 Elsevier. (C) As CuNPs content increased in concentration, the value of CFU (number of microorganisms) decreased. Reprinted with permission from [12]. (C) (left): Diagrams of strength-strain obtained with Instron for treated fabrics; (right): Disk-diffusion test against S. aureus microbial growth for (a) untreated nylon fabric (b) CuNPs treated nylon fabric. Reprinted with permission from [57]. Copyright 2013 Elsevier. 


\section{Migration Behavior of Nano-Silver/Copper in Composite Film}

In recent studies, the issue of limited publication has been identified in determining the rate of NP migration from food packaging to food and beverage (Figure 3A). Metals usually migrate when foods come in contact with packaging materials. The phenomenon of migration comprises three stages: migrant (NP) diffusion, dissolution, and dispersion in food. Choi and his colleagues reported that even babies' health can be negatively affected by the migration of embedded NPs, such as AgNPs from baby products (Figure 3B) [60]. Understanding NP migration is essential to assess the potential health impact of these substances in contact with foods [61]. In particular, the degree of NP migration may be affected by the inherent effects of physicochemical properties of other components in foods [62]. Many studies on the migration of NPs have avoided addressing the problem of analyzing them in real food matrices; only a few methods have been employed to assess the mass transfer process and estimate the specific and overall migration of substances into food simulants.
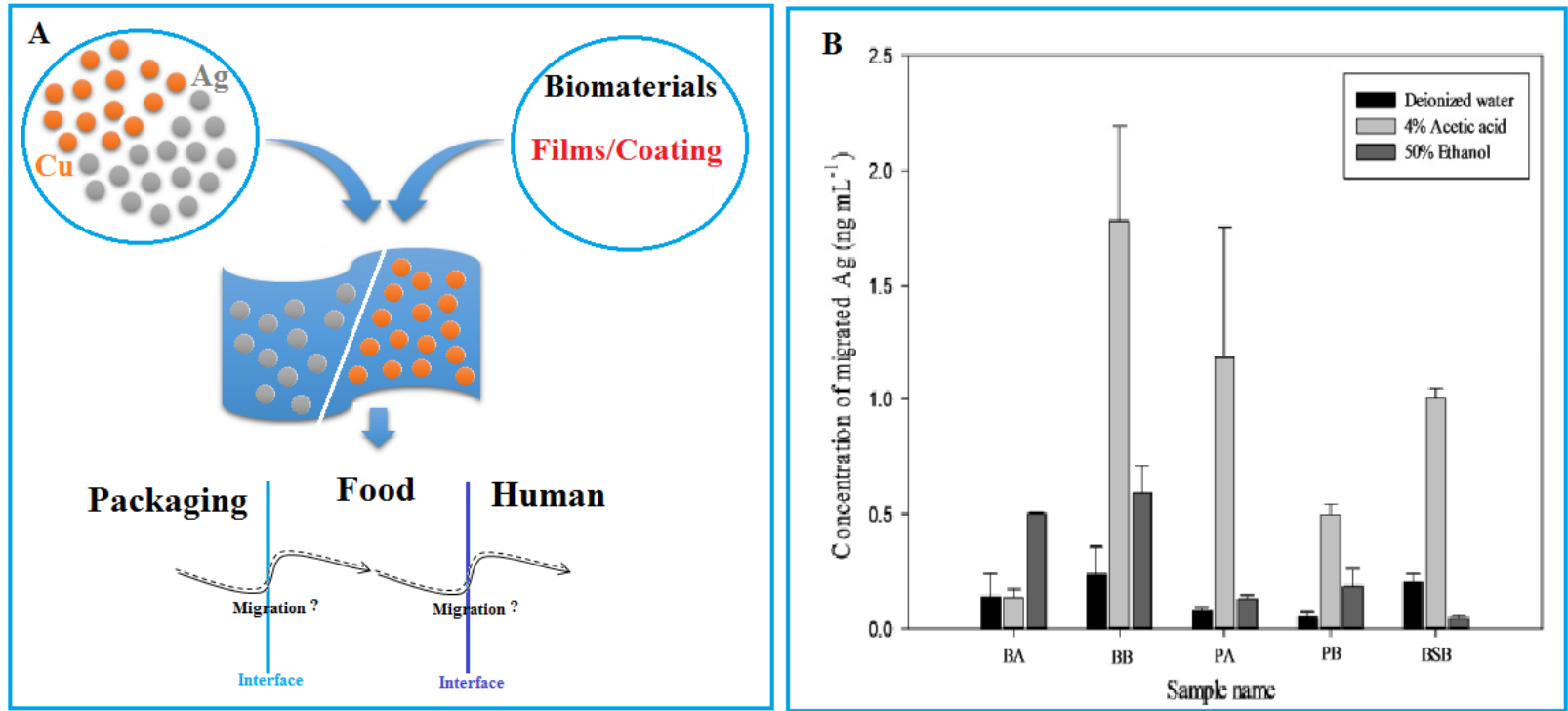

Figure 3. (A) The issue of AgNP and CuNPs migration from packaging to foods and from foods to human organs. (B) Concentration of migrated AgNPs in three different food simulants from baby bottle A (BA). BA: baby bottle A; BB: baby bottle B; PA: pacifier A; PB: pacifier B; BSB: breast milk storage bag. Reprinted with permission [60]. Copyright 2018 Taylor \& Francis.

The migration of materials from packaging to food is highly complex and is expressed by two mechanisms of diffusion and adsorption. Emission is the transfer of matter by the random motion of molecules from a high-concentration region to a low-concentration region until equilibrium is reached. The degree of influence according to Fick's second law is equal to the following relation.

$$
\partial C_{\mathrm{p}} / \partial t=D\left(\frac{\partial^{2} C}{\partial x^{2}}\right)
$$

where $C_{P}$ is the concentration of the migrating material in the polymeric material, $D$ is the diffusion coefficient, $t$ is the penetration duration, $x$ is the distance between the package and the food. Here, " $D$ " as the most significant factor influences the migration rate. The diffusion process lies in several factors including food contact, packaging material, the nature of foods, storage time, and storage conditions. In addition, it was reported that by opening the packaging, the rate of diffusion will alter [63].

The adsorption phenomenon is known as controlled mass transfer due to contact of food with other substances, which leads to an initial increase in the concentration 
of molecules at the interface of the food/packaging material. The number of adsorbed molecules at a given temperature is expressed by the Freundlich relation:

$$
\frac{x}{m}=\mathrm{k}_{\mathrm{p}} \times \frac{1}{\mathrm{n}}
$$

where $x$ is the mass of the adsorbed air; $m$ is the amount of matter absorbed under the pressure of $\mathrm{P}$; and $\mathrm{k}_{\mathrm{p}}$ and $\mathrm{n}$ are constants [64].

\subsection{Migration Experiments}

The European Commission (EC) has established regulations and restrictions specifying the conditions in which migration tests are mandatory. It also proposed several food simulants, including water, acetic acid ( $3 \% v / v)$, ethanol $(10 \% v / v$ and $50 \% v / v)$, and vegetable oil based on the food's type in contact with the packaging. Thus, most migration studies employing such simulants and evaluation of the NP migration into actual foods are lacking.

Efforts to promote instrumentation and strategies through the analysis of foods experienced a lack of analytical tools. This field will entail more investigation. Regulatory authorities can cause limitations on NP usage in foods. The invention of instruments, which includes an apparatus to assess engineered NPs, has been deemed mandatory. It is important to be able to perform NP identification, size measurement, and its distribution in ways that must be noninvasive and unrestrictive [65]. In this approach, a substrate covered by NPs is considered as a reference material, and it is used in combination with analytical and imaging systems that focus on screening techniques such as mass spectroscopy (test material composition), dynamic light scattering (DLS; particle size distribution), positron emission tomography (radio-tracing), spectroscopy (NP size), and optical emission spectrometry (trace level elemental analysis) for monitoring and collecting adequate information. Another technique for food evaluation in the viewpoint of harmful substances employs a sensor-based system that included NPs in solution or nanostructured surfaces that are able to respond to changes in the adsorbate electronic states (chemical signal enhancement) and changes in metal roughness (electromagnetic signal enhancement), where the chemisorption of the analysis at the NP surface of the biosensor is the main mechanism [66]. In another technique, a system to detect food safety named Raman Nano Chip $^{\mathrm{TM}}$ [67] utilizes nanorods to adsorb or collect test samples under the adsorption of molecules onto the surface of the nanostructure. For more utility and applicability, sensors may be covered or coated with NPs in the form of a colloidal suspension of polymeric, metallic, or oxide NPs.

To measure nanomaterials in complex matrices, analysis techniques must make an explicit difference between NPs and other components in the matrix, and the employed methods must be sensitive enough to monitor the matters in low concentrations [68]. On the other hand, a single analysis cannot guarantee the determination of NP migration in all foods and food simulants, at all temperatures, and therefore it is important to utilize several tests to obtain accurate results. Table 1 shows a brief report of the test methods used to study different aspects of nanobased systems, including food packaging (as discussed by dos Santos [69]). These methods also provide sufficient information about the composition, concentration, and physicochemical properties of the nanomaterials in the sample; however, it is not possible to determine the true amount of NPs in the food texture. According to the complexity of the networks, combined methods may give more reliable results in quantifying and identifying NPs, whereas independent methods are likely unable to determine all the information [70]. During the engineering of novel FPSs, migration testing is one of the main steps. Tracing NPs and the validation of their responsibilities are important for FPS designing. 
Table 1. A list of common tests employed in food packaging studies.

\begin{tabular}{ll}
\hline \multicolumn{1}{c}{ Purpose } & \multicolumn{1}{c}{ Tests } \\
\hline Shape & TEM, AFM \\
Size & TEM, NMR, XRD, DLS, NTA, SEM, AFM, DCS, ICP-MS, UV-Vis, FMR \\
Crystal structure & XRD, HRTEM, electron diffraction, STEM \\
Surface area, specific surface area & liquid NMR, BET \\
Surface charge & Zeta potential \\
Size distribution & ICP-MS, DCS, DLS, NTA, FMR, DTA, TRPS, SEM \\
Concentration & ICP-MS, PTA, UV-Vis, RMM-MEMS, \\
Agglomeration state & Zeta potential, TEM, SEM, DLS, UV-Vis, Cryo-TEM, \\
NP dispersion of in matrices/supports & SEM, AFM, TEM \\
\hline
\end{tabular}

Common chromatographic methods for polymer additives are limited and unsuitable because they cannot measure the physicochemical properties of NPs. Therefore, only a limited number of methods work efficiently for detecting and characterizing NPs.

High resolution imaging such as electron microscopy (EM) is one of the most suitable methods for identifying and imaging the shape and structure as well as the size and density of NPs in the food matrix, including scanning electron microscope (SEM), transmission electron microscope (TEM), and atomic force microscopy (AFM) (Figure 4A). Particle count is very time-consuming, and since these methods have destructive effects on the samples, the sample cannot be re-evaluated by other methods [71]. The use of TEM is also appropriate when the matrix is made of polymers, but in case of other methods, it is necessary to detect migration in complex environments like food or quasi-food [72].

Inductively coupled plasma with mass spectrometry (ICP-MS), atomic emission (ICPAES), and optical emission spectroscopy (ICP-OES) as quantitative analysis methods are among the most important and practical methods for the determination of metal NPs (Figure 4B-I). ICP-MS is employed to determine the quantification and elemental composition characterization of NPs in a single but fast analysis, i.e., SP-ICP-MS (SP stands for single particle). The reason is its high sensitivity and potential for identifying and quantifying metals and its better selectivity than other methods in this category [73]. ICP-MS showed that it provides more reliable results when in incorporation with other techniques. Laser ablation (LA) ICP-MS is used for the qualitative determination of Ag content [74]. According to the results, the regulation limits for both $\mathrm{Ag}$ and $\mathrm{Cu}$ were defined as $<0.08 \mathrm{mg} / \mathrm{kg}$ and $<4 \mathrm{mg} / \mathrm{kg}$, respectively, while the limits of determination in ICP-MS were $0.03 \mathrm{mg} / \mathrm{kg}$ and $0.01 \mathrm{mg} / \mathrm{kg}$, respectively [75]. Atomic absorption spectroscopy (AAS) is an alternative with a higher speed and sensitivity than ICP methods, but this method is not suitable for multielement analysis (Figure 4B-II).

Spectroscopic methods including X-ray diffraction (XRD) give information such as the elemental composition or aggregation and structure of nanomaterials (Figure 4C-I) [76,77]. These methods have a wide range of applications due to their nondestructive nature. Spectroscopy is used as a backup method due to its low cost and ease. Energy dispersive X-ray spectroscopy (noted as EDS/EDX) is known as a chemical microanalysis technique employed in conjunction with SEM, conducted to identify the component, size, and shape of NPs (Figure 4C-II).

NP tracking analysis (NTA) and dynamic light scattering (DLS) use the properties of both Brownian motion and light scattering in order to measure the NP size distribution of the samples in suspension. The technique is known as a nondestructive test, and if required, the sample can be recovered [78]. DLS has been widely employed in studying the size distribution of NPs in colloidal suspensions in the nano- or submicrometer ranges before embedding the NPs in films or coating. The suspension concentration, particle shape, colloidal stability, and surface coating of NPs influence the size value obtained by DLS measurements. DLS is much more sensitive to the presence of aggregates.

The titration method has a higher sensitivity in terms of measuring the amount of NPs released. This method also provides more accurate information than the migration 
method and allows for the determination of the number of NPs released from the coating of polymer packages that were exposed to heat [79]. The migration method is an old method and is used for other coatings, while according to the US National Standards Organization EN-1186 and 11737-3, this method is the best option for nylon, polystyrene, PVC, and poly ethylene terephthalate (PET), and it is unsuitable for NP coatings. However, the titration method is an up-to-date approach and is a commonly used method all over the world [80].
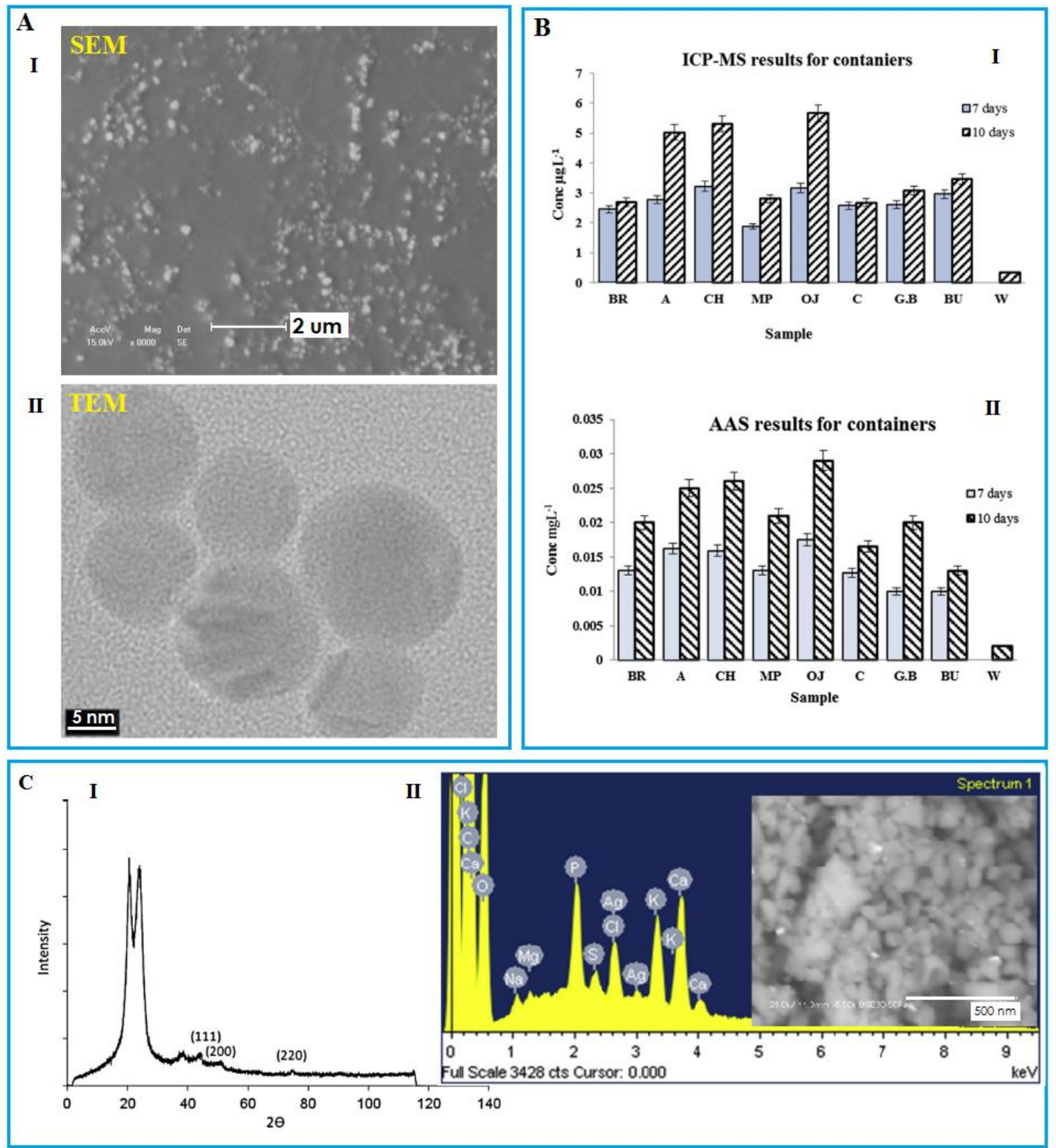

Figure 4. (A) I: SEM illustration of the AgNPs synthesized by the modified polysaccharide. Reprinted with permission from [82]. Copyright 2017 Elsevier; II: TEM image shows the migration of AgNPs detected from an orange juice sample under storage by a nano-silver coated film packaging at $40{ }^{\circ} \mathrm{C}$ for 10 days. Reprinted with permission from [81]. Copyright 2015 Elsevier. (B) I: Inductively coupled plasma mass spectrometry (ICP-MS); II: Atomic absorption determination of Ag from different food samples stored using nanosilver containers for 7 and 10 days at $40{ }^{\circ} \mathrm{C}$. (C) I: XRD spectrum of nylon fabric treated by copper NPs. Reprinted with permission from [57]; II: EDS and SEM images indicate silver NPs as white spots detected inside the milk powder stored using nanosilver coated film packaging for 10 days at $40{ }^{\circ} \mathrm{C}$. Reprinted with permission from [81]. Copyright 2015 Elsevier. 
Using ICP-MS and AAS, commercial nanocomposite food packaging in the form of nanosilver coated films and containers were evaluated in real-food matrices to measure the degree of NPs incorporation [81]. Migration testing was done for a range of food materials packaged in various packaging materials at $40{ }^{\circ} \mathrm{C}$ for ten days. Water and $3 \%$ acetic acid were also used for identifying the factors that have an impact on migration.

\section{2. $\mathrm{Cu} / \mathrm{Ag}$ NPs Migration}

As the use of NPs in various packages may have adverse effects on animal and human cells, legislators have established rules to measure and study the migration of NPs to food (Table 2). The diffusion, dissolution, and abrasion of the packaging surface can be considered as reasons for the migration of nanomaterials from packaging to food [83]. Scientists have suggested that AgNPs are mandatory for achieving antimicrobial activity by using AgNP in reinforced thermoplastic polymers, such as polyethylene (PE), polypropylene (PP), polystyrene (PS), or nylon [84].

Although the benefits of nanotechnology have led to the use of industry and the public to make greater usage of nanobased materials, careful research is needed to determine the likelihood of NPs migrating from any concentration to packaged materials, as toxic effects for high concentrations of nanomaterials were proven. Research shows that there are migrants such as silver and copper [85]. Due to the expensive instruments, difficult analysis, and food matrix disturbances, few studies have been carried out on NP migration [86].

Determining the maximum migration of NPs to food is one of the most important concerns in the food industry. Migration is defined as a mass transfer for low molecular weight particles. General and specific migration tests have limitations for each food, and these limits are set by the EFSA (European Food Safety Authority) and the FDA (Food and Drug Administration). According to the EFSA definition, a migration test is the measurement of the amount of transport and release of packaging components (such as NPs) into food or food stimulants [87].

It is very important to perform a migration test during the production process of a material to provide new packaging for foods. Although numerous papers have covered the migration of other NPs, such as nanosilver [73], nanoclay [88], and nano- $\mathrm{TiO}_{2}$ [89], few studies have been conducted on CuNPs migration from packaging into food or food simulant, and researchers are mainly studying the way to increase the barrier properties, mechanical features, antimicrobial activities of those copper nanocomposites which are potentials for food packaging, and ultraviolet light stability.

\subsubsection{AgNP Migration}

Although numerous studies have been carried out on the synthesis of AgNPs and their application in packaging systems, few studies have been conducted on the detection and migration of harmful substances in AgNPs-based FPS. Additionally, the previous studies about AgNP migration from packaging resulted in contradictory conclusions on AgNP detection. Several researchers have reported the presence of NPs in food [90,91], while other studies have provided no evidence of NP migration and supported these results with physicochemical modeling [92,93].

Amal M. Metak et al. [81] focused on the migration of AgNPs from coated nanosilver films and AgNP-based and commercial food packaging in juice as real-food matrices. Conversely, samples exposed to nanosilver coated films revealed higher levels of migration $\left(\leq 0.03 \mathrm{mg} \mathrm{L}^{-1}\right)$, which is cautionary whether in the form of a NP or ionic metal. No chemical or biochemical changes were observed in the tested food samples.

Cushen and colleagues studied AgNP migration from synthesized nanocompositebased PVC (polyvinyl chloride) in contact with chicken breasts (at temperatures between 5 and $20^{\circ} \mathrm{C}$ ) and carried out migration tests. The results depicted the levels of migration equaling $0.03-8.4 \mathrm{mg} \cdot \mathrm{kg}^{-1}$ [94]. Based on the studies conducted by Song et al. [73] on the migration of AgNPs from polyethylene packaging to the food web, results from the ICP-MS analysis showed that the rate of silver migration in acetic acid 3\% is time-independent and 
temperature-dependent, while in ethanol $95 \%$ o the amount of nanosilver migration was time-dependent, and temperature changes showed no significant effect. In addition, Lin et al. [89] studied AgNP migration by ICP-MS and ICP-AES methods and found that the most important step in these techniques is sample digestion. It was also reported that the ICP-MS method is more accurate than the ICP-AES method for detecting the migration of silver NPs.

In a study done by Hosseini et al. [79], titration and migration methods showed different results for silver NP residues in prepared coatings containing $5-8 \%$ NPs. Although no significant difference was reported between the emitted NPs in coatings containing 1-3\% of NPs, a statistically significant difference was reported between the two methods at $5 \%$ and $8 \%$. Findings from another study revealed that just very small concentrations of silver migrate from food packaging when in contact with acidic and aqueous food simulators in the form of ionic silver $(\mathrm{Ag}+)$. It was also found that the migration of silver from this type of food packaging seems to be mainly a surface process, and any conditions that lead to significant changes in surface properties may affect the silver concentration in the simulator [95].

In a study by Carsten Engelhard [96], by employing capillary electrophoresis coupled to ICP-MS for measuring AgNPs, it was suggested that AgNPs with polymeric coatings are more chemically stable compared with citrate coatings, and therefore they may reduce the reactivity and evolution of NPs in the environment, but more studies are needed to optimize their antibacterial impact while controlling their environmental hazardous (due to their migration). In another study done by Ahari and his colleagues, the migration of AgNPs into the caviar samples was also studied by the titration method and the application of tetrazole with concentrated sulfuric acid. No silver residual was reported from packages with various concentrations of AgNPs [59].

In research done by Yolanda Echegoyen, three distinct commercialized food AgNPbased containers were studied. The migration of silver in the form of dissolved silver and silver NPs was conducted as a key aspect of the toxicity. Based on the results, migration values were very low, although the EU (European Union) provided no specific limit for nanomaterials. The size $(10-60 \mathrm{~nm})$ and morphology of the AgNPs were distinct for the samples. They also confirmed the migration of other nanoscale materials [91].

The antibacterial effect of the migrants needs to be evaluated during storage. In this regard, Raul and his colleagues surveyed the Ag release from commercially food packaging to simulants (water, acetic acid, olive and ethanol-water) and also the antimicrobial capacity of the migrated silver in meats (turkey, tuna, and ham). Silver also showed its potential in migration in the form of $\mathrm{Ag}^{+}$ion and AgNPs. Nevertheless, a significant antibacterial performance of the migrated silver to the turkeys was observed for gram-negative bacteria. In addition, in comparing various packaging including food touch papers, cutting boards, containers, and bags, the higher level of release belonged to paper $(25 \pm 11 \mathrm{mg} / \mathrm{kg})$ [97]. It was also reported that the silver ion release rates decrease with enhancing $\mathrm{pH}$ and NP size while they increase with temperature [98]. The oxidative attack of the AgNPs is known as a time-dependent chemical reaction and is the reason why for all samples under study, the level of the migrated silver is higher for the longer essays (even at low temperatures).

\subsubsection{CuNP Migration}

Unlike silver, there is a low percentage of studies on the migration of CuNPs from packaging coatings to food. In one study, a migration experiment was conducted to assess the impact of time and temperature on the CuNP/AgNP migration from polyethylene nanocomposites to chicken breasts [58]. Copper and silver migration ranged from 0.024 to $0.049 \mathrm{mg} / \mathrm{dm}^{2}$ and 0.003 to $0.005 \mathrm{mg} / \mathrm{dm}^{2}$, respectively. Based on the results, time and temperature did not have any significant effect on migration. These results were verified by the proposed equation of Williams-Landel-Ferry for time-temperature superposition. Compared to the AgNPs, CuNPs showed an enhanced dissolution rate from the coating 
as a result of their smaller size, which was reported as one of the vital reasons for higher migration [99].

Liu and her colleagues studied the migration of CuNPs from copper-coated films via simulants including acetic acid (3\%) and ethanol (10\%) by GFAAS and ICP-MS. Based on the results, copper migration was significantly lower in $10 \%$ ethanol, and the migration ratio was lower than limitations from FDA. It was concluded that copper migration from nanocomposite films is affected by the temperature, time, initial concentration of CuNPs in the films as well as contact media [85]. Surprisingly, these results were not in agreement with those of the study done by Cushen [58]. It was also shown that the addition of an additive with no chemical bonds can promote copper migration. The addition of CuNPs alters the morphology of the film surface, which results in more surface area. The more surface area, the higher the contact between the food and the film, which accelerates and increases copper migration [85]. In a similar study, based on migration tests, if the initial concentration of CuNPs that is added into the polypropylene film reached $1 \%(w / w)$ whereas the real concentration of CuNPs within the film was $0.79 \%$, then the concentration of copper migrating from the film to the acetic food simulant $(3.0 \%)$ would reach to $4.5 \mu \mathrm{g} / \mathrm{g}$ and would damage the liver cell [100].

\section{Film Production Methods for Food Packaging}

Polyamides (PA), nylons, poly ethylene terephthalate (PET), polyolefins, polystyrene (PS), ethylene-vinyl acetate (EVA) copolymer, epoxy resins, polyurethane, and polyimides are of the commonly employed polymers in food packaging [101]. According to reports, the combination of biomaterials and metal NPs in films can promote certain properties such as antibacterial, mechanical strength, barrier properties, and thermodynamic properties [102]. At present, a variety of polymer-based nanocomposites are used in FPS for meats, fruits, vegetables, and beverages $[103,104]$. There are some methods such as melt mixing by which biopolymeric-based films are produced for FPS in which metal NP migration varies [105]. Powder process, spray pyrolysis, rapid solidification, chemical vapor deposition, physical vapor deposition, solution mixing, solution casting, and in situ intercalative polymerization are other methods for NP-based composite preparation, which were discussed by Ajay Vasudeo Rane et al. [106].

Mihaly Cozmuta prepared an $\mathrm{Ag} / \mathrm{TiO}_{2}$ nanocomposite via sol-gel procedure to increase bread shelf life [107]. Based on the results from XRD, TEM, and FTIR, it was concluded that the $\mathrm{TiO}_{2}$ particles had a well-defined form, and the structure of the $\mathrm{Ag}-\mathrm{TiO}_{2}$ composite was also formed. Similarly, in one of our previous studies [108], LDPE / $\mathrm{TiO}_{2} / \mathrm{Ag}$ nanocomposite films were produced by the techniques of melt mixing and sol-gel. The films prepared via the sol-gel technique revealed weak inhibition zone diameters (gram + and gram -) in contrast with those by melt mixing, and consequently a longer shelf life was reported for melt mixing based films. Due to the lack of organic solvents, the melt composition is environmentally much safer. The melt composition is compatible with the common industrial processes, including injection molding and extrusion [108].

In one study, chitosan/PVA/AgNPs films were prepared by the electrospinning technique for increasing fresh food shelf life [109]. Composite packaging not only possessed an antimicrobial property but it was also recommended for replacing plastics and have a low environmental impact due to its low migration. In another study, the solution casting method was used to make an Ag/gelatin-based composite film. As well as other techniques, acceptable results regarding antimicrobial effects were concluded [110]. It was shown that the components of the composite including the biopolymer and also the metal(s) affect the final quality of the prepared film and also degradation and migration processes. For instance, Marilena Carbone et al. [26] conducted a review study in which their outcomes showed that microwave heating, acidic food, and the use of nanofillers can enhance the migration of $\mathrm{Ag}^{+}$, and the actual $\mathrm{Ag}^{+}$concentration stay below the limits legislated by safety authorities. 
In another study, Emamifar and his colleagues evaluated the migration of both $\mathrm{Zn}$ and Ag from LDPE-Ag-ZnO nanocomposites into orange juice [111]. Nanocomposites were made by the melt mixing process through a twin-screw extruder. They reported that both $\mathrm{Zn}$ and $\mathrm{Ag}$ have migrated in low concentrations $(0.68$ and $0.15 \mu \mathrm{g} / \mathrm{L}$ for $\mathrm{Zn}$ and $\mathrm{Ag}$, respectively), and after 112 days of storage in the refrigerator, they remain within the allowable limits for consumers.

Table 2. Applications of Ag/Cu NP systems in food packaging, their effect under study, and analytical methods for their determination.

\begin{tabular}{|c|c|c|c|c|c|}
\hline Biopolymer & Nanoparticle & Food Source & Effect under Study & NP Analytical Tests & Ref. \\
\hline LDPE & $\mathrm{Ag}$ & $\begin{array}{l}\text { Food simulants ( } 3 \% \\
\text { acetic acid, } 50 \% \text { ethanol } \\
\text { and distilled water) }\end{array}$ & $\begin{array}{c}\text { Developing } \\
\text { antibacterial and acid } \\
\text { food packaging system }\end{array}$ & $\begin{array}{l}\text { TEM, UV, } \\
\text { ICP-MS }\end{array}$ & [49] \\
\hline PLA & $\mathrm{TiO}_{2}+\mathrm{AgNPS}$ & Mangoes & $\begin{array}{l}\text { Effectiveness } \\
\text { against total } \\
\text { bacteria count }\end{array}$ & - & [112] \\
\hline $\begin{array}{l}\text { Polyethylene } \\
\text { plastic bags }\end{array}$ & $\mathrm{Ag}$ & $\begin{array}{l}\text { Water, acid, alcohol and } \\
\text { fatty foods }\end{array}$ & Migration & SEM, EDX, AAS, & [113] \\
\hline $\begin{array}{c}\text { Polystyrene- } \\
\text { polyethylene oxide } \\
\text { block }\end{array}$ & $\mathrm{Ag}+\mathrm{Cu}$ & Acidic food simulant & $\begin{array}{l}\text { Migration and Human } \\
\text { health }\end{array}$ & $\begin{array}{l}\text { NTA, TEM, ICP-AES, } \\
\text { SEM, TEM }\end{array}$ & [99] \\
\hline Polypropylene & $\mathrm{Cu}$ & $3 \%(w / w)$ acetic acid & $\begin{array}{l}\text { Film appearance, } \\
\text { mechanical and } \\
\text { thermal improvement, } \\
\text { great antibacterial } \\
\text { ability }\end{array}$ & $\begin{array}{l}\text { FTIR, FE-SEM, } \\
\text { ICP-OES }\end{array}$ & [100] \\
\hline PLA & $\mathrm{TiO}_{2}+\mathrm{Ag}$ & Yunnan cottage cheese & $\begin{array}{c}\text { Inhibitory effect } \\
\text { against total } \\
\text { bacteria count, yeasts } \\
\text { and } \\
\text { molds growth }\end{array}$ & ICP-AES & [114] \\
\hline LDPE & AgNPs & $\begin{array}{l}\text { Distilled water and } \\
4 w / v \% \text { acetic acid }\end{array}$ & $\begin{array}{l}\text { Migration and silver } \\
\text { release rate }\end{array}$ & $\begin{array}{l}\text { TEM or SEM, FTIR, } \\
\text { XRD, UV-Vis, ICP-MS }\end{array}$ & [115] \\
\hline PVC & AgNPs & $\begin{array}{l}\text { Walnut, hazelnut, } \\
\text { pistachio almond }\end{array}$ & $\begin{array}{c}\text { Decrease total bacteria } \\
\text { count } \\
\text { and coliform }\end{array}$ & - & [116] \\
\hline LDPE & $\mathrm{CuO}+\mathrm{ZnO}$ & Ultra-filtrated cheese & $\begin{array}{l}\text { Decrease in the most } \\
\text { probable number of } \\
\text { coliforms }\end{array}$ & - & [117] \\
\hline LDPE & $\mathrm{Cu}$ & Peda & $\begin{array}{l}\text { Enhancing mechanical } \\
\text { properties, superior } \\
\text { antimicrobial effect }\end{array}$ & $\begin{array}{l}\text { UV, XRD, TGA, DLS, } \\
\text { FTIR, FE-SEM }\end{array}$ & [12] \\
\hline
\end{tabular}

It is recommended that the method of film preparation is just one of the effective reasons for migration. In one study, silver diffusion from nanosilver-polyethylene composite films into acetic acid (3\%) under various migration test methods was assessed to find out the effect of exposure conditions on silver release [49]. As a conclusion, the impact of the method of migration test on the nanocomponent release is different from that on the common migrants migration. Therefore, to remove or minimize any potential negative effects on the obtained results, the exposure condition must be considered in the design of the migration test for nanobased composite films. 


\section{Discussion}

In this study, we provided a brief discussion about the place of Ag/Cu NPs in the food packaging industry by covering the way that they are used and the positive and negative effects that they leave in food and human health.

There is a likelihood that the packaging process can leave a serious impact on the nutritional and organoleptic properties of food from production until consumption due to migration and chemical reactions. Migration as the main concern of this study will start when the packaging system comes into contact with foods, fruits, and vegetables. In this case, the packaging system acts as a chemical source [118]. Migration showed a direct effect on food quality. As discussed, the amount and the rate of chemical (NP) mass transfer depend on various factors, such as the method of producing packaging coating/film, the nature of the material, the concentration of NPs, environmental conditions (such as oxygen and temperature), time, and type of food.

Previous studies reported two claims about the hazards of novel nano packaging: (i) There is evidence about NP transferring from food packaging to foods, and (ii) there is no sign of food contamination by NPs. When the migration of nanoparticles occurs, the NPs penetrate into the food matrix. If the concentration of the transmitted NPs exceed the standards, this is dangerous and hazardous to human life. In this case, it does not matter whether the presence of NPs is safe for the food or not. In cases where the concentration of migratory NPs is below the standard, on the one hand, there is no danger to human health, and on the other hand, NPs prevent the growth of microorganisms and fight bacteria. However, studies have shown that NPs are now present in many processed and natural foods, and new types of NPs may be used as functional materials in the future by the food industry, including packaging. Many of these NPs are thought to affect human health, and there is evidence that some of them could have detrimental effects and need further study. Further studies are also needed on the negative effects of NPs on food itself [119]. It is hypothesized that the presence of NPs may react with water, oxygen, fats, carbohydrates, minerals, and proteins within the food matrix. Although there are some food-grade NPs, but the final products may be hazardous to human life, and therefore more studies are required to answer this question in detail.

It has been stated that water and organic molecules are first embedded in the interlayer and that they eventually plasticize and expand the space between the polymer chains, which can accelerate the subsequent diffusion into foods. Adsorption equilibrium stimulates macromolecular chains, especially in the amorphous region and then, the oxidized NPs (like AgNPs) can cross the diffusion barrier and finally migrate through the balanced sample [113].

It is important to determine NP migration under real conditions, but this is difficult to perform and therefore has been replaced by the simulation of the migration process. Both claims above were revealed based on the results obtained from these simulations. Keeping this issue in mind, the employed methods and their results are found in other documents that discuss NPs migration, which is another challenge because of (1) the interdisciplinary nature of nanotechnology, (2) the lack of appropriate reference (standard) materials for analytical tools or calibration, and (3) the problems associated with sample preparation for data analysis and interpretation [120]. In addition, there are challenges in NP monitoring that, based on our research, have not been addressed in previous studies, such as measuring their concentration in situ and on-line, especially in a low production (scale-up) and analyzing them in complex matrices.

Size and shape are two of the well-known parameters of NPs. There are methods that give results about both parameters, while they may be different (Table 1). The measurement of size distribution, aggregation degree, crystal structure, concentration, surface area, and also surface charge are another parameters that need to be evaluated during NP-based food packaging [121].

There are several methods including ICP-MS, ICP-OES, XRD, DLS, DTA, FTIR, SEM, TEM, UV-Vis, AFM, NMR, and so on for monitoring NPs, and these were reviewed as 
a robust guide in detail by Thanh et al. [120]. Each of these methods alone can provide useful information about the presence and condition of NPs in food packaging, but they also have weaknesses. Moreover, using two or more techniques as a complement to each other gives more valid results; to access more reliable results, it is recommended to employ numerous techniques.

Migration test methods showed an impact on the silver release from nanosilver-based polyethylene films. The contact between the coating (film) and the food plays a main role in silver migration. The connection in two sides revealed higher silver migration than just a one-sided contact. Knowing how long the connection lasts is important because when the exposure time is low, less migration occurs [122]. In one study, scientists focused on metal migration from ceramic food contact materials and reported that the migration rate increases by increasing the contact duration [123]. Lei Zhu and his colleagues reported that when the concentration of the NPs within the polypropylene film invades from $0.79 \%$ and reaches $1 \%$, Cu migration will happen [100]. In a similar study, the concentration of CuNPs and AgNPs was monitored via the method of thermally-assisted acid digestion and then by an ICP-AES technique. Since the ICP-AES was unable to distinguish between NPs and ionic metal, no significant difference was found between the initial concentration of $\mathrm{AgNP}$ and CuNP in coated slides because both coated materials were saturated with NPs. In this regard, higher migration was reported for both NPs. Surprisingly, a TEM analysis confirmed the absence of NPs in a food simulant [99]. In this regard, the reason may be the low concentration of NPs, and it is suggested that the main migration mechanism might be NP dissolution from the surface and the cut edge of the film and then a fast dissolution in the food simulant. It was also revealed that if the concentration of CuNPs raises, the migration rate of CuNPs from LDPE composite films to the food simulants will increase [85]. Wang and his colleagues reported a similar reason for $\mathrm{TiO}_{2}$ migration from $\mathrm{PLA} /$ nano-TiO2 composite films [124]. In this regard, Ozaki et al. [86] stated that the rate of metal NPs migration gradually increases until it reaches an equilibrium.

The migration of AgNPs from polyethylene bags into food simulants was investigated where after 10 days of storage at $25{ }^{\circ} \mathrm{C}(4 \%$ acetic acid), the maximum migration rate equaled $8 \mathrm{ng} / \mathrm{cm}^{2}$ [113]. By employing $5 \%$ acetic acid after 7 days of storage, the total concentration of $0.9 \mu \mathrm{gL}^{-1}$ was determined [125]. Although in both studies the initial concentration was not measured, it is obvious that the difference between the acetic acid concentrations may alter the NP migration rate. It was previously reported that a reduction in $\mathrm{pH}$ can increase metal migration, and a linear relationship was observed between the metal concentration and $\mathrm{pH}$ levels. In another study, it was reported that the simulants with higher acidity resulted in a larger quantity extraction of NPs in some cases, and sometimes no significant differences were observed. It was also reported that the source of acidity (acetic acid or citric acid) does not affect this behavior (Figure 5A) [123]. Keeping this controversy in mind, Wen Li et al. [49] reported that the rate of migration does not depend on the food type and temperature. They employed three food simulants (3\% acetic acid, $50 \%$ ethanol, and distilled water) and monitored AgNPs migration at three temperatures $\left(25,40\right.$, and $\left.70^{\circ} \mathrm{C}\right)$. Noticeably, it was reported that migration is time-dependent, and as time passes, more migration happens. As previously mentioned, reaching an equilibrium will stop NP migration. For instance, in a study by Wang and his colleagues, high migration was reported during the first few days, but when time migration was raised, an equilibrium and steady-state appeared for 25 days (Figure 5B-I) [124]. The results from the study by Von Goetz et al. were against these reports; they stated that the Ag content in the food simulants enhances with incubation time (Figure 5B-II) [126].

There is a likelihood that silver can be detected in the form of NP or ionic form. It was reported that Ag in acetic acid (4\%) was mainly monitored ionically, whereas in distilled water and ethanol (20\%) were in the form of NPs. Figure 5 depicts that the NP form of metals, including $\mathrm{Ag}$ and $\mathrm{Cu}$, has a higher tendency for migration. To differentiate between ions migrated Ag and NPs, the ultra-filtration experiment, which is deemed quicker, less technical, and less expensive compared to other techniques, was performed [86]. 
A $\quad$ Acetic acid (AA)

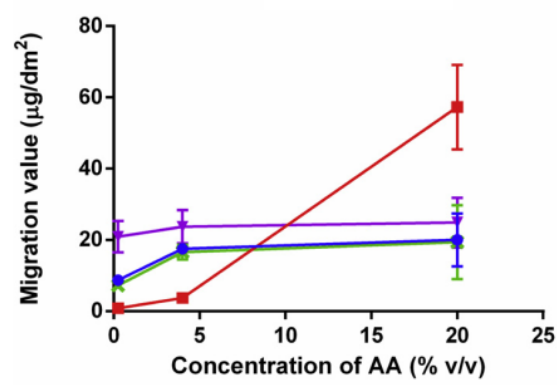

Citric acid (CA)

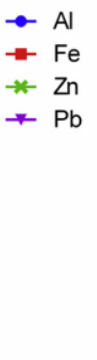

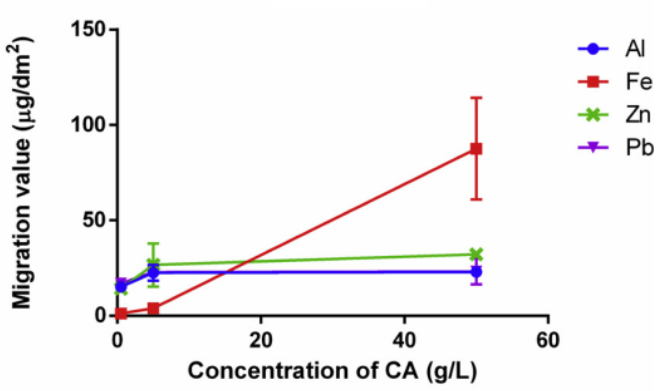
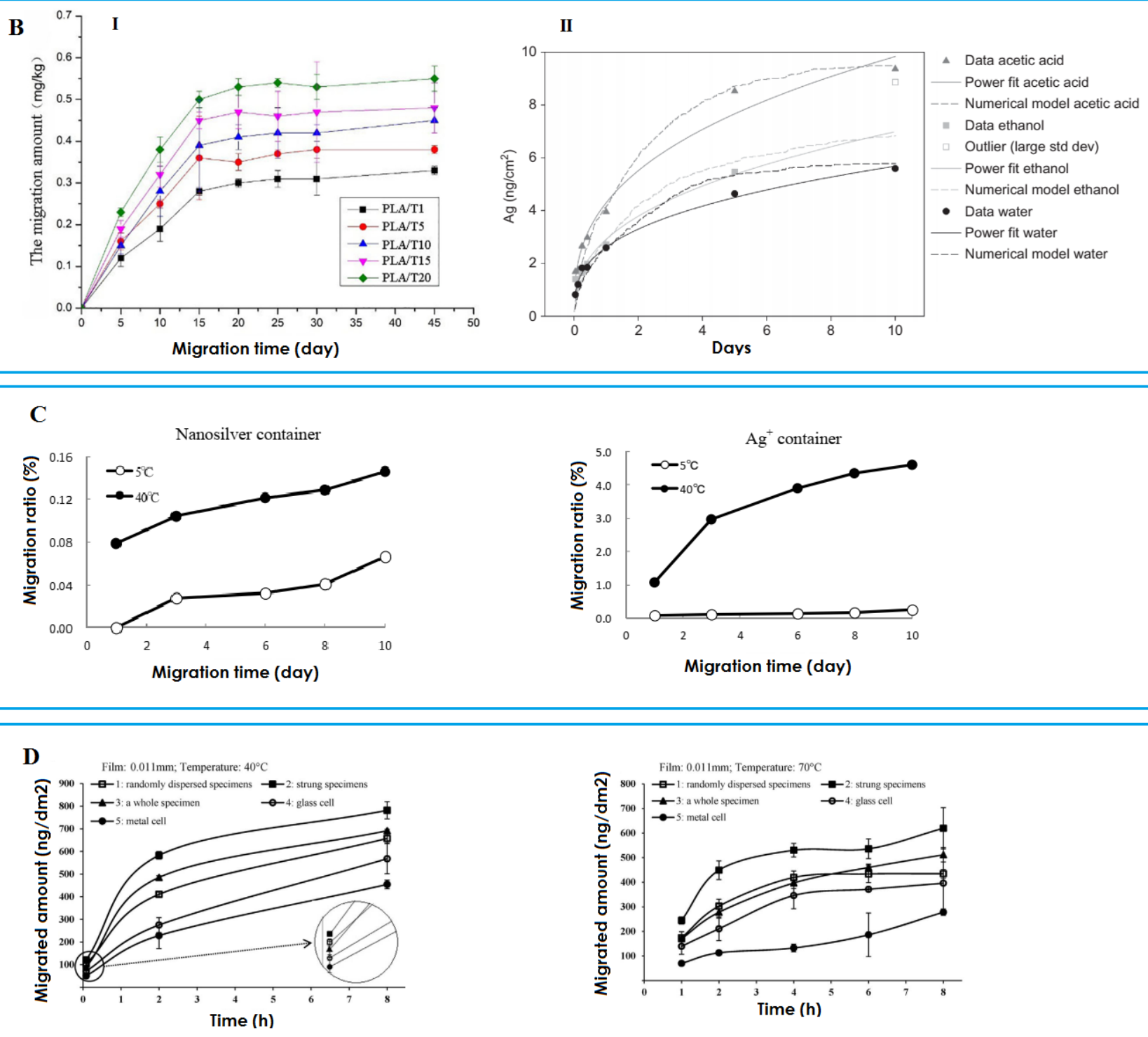

Figure 5. (A) Migration of metals (Al, Ba, Fe) into $0.25 \%, 4 \%$ and $20 \%$ acetic acid (AA) and citric acid (CA). Reprinted with permission from [123]. Copyright 2020 Elsevier. (B) I: The effect of time on the rate of nano- $\mathrm{TiO}_{2}$ migration from the various nanocomposite films made of PLA stored for 45 days; II: Ag migration from food container into the various food simulant at $20^{\circ} \mathrm{C}$. Reprinted with permission from [124]. Copyright 2019 Elsevier. (C) The temperature impact on Ag migration curve in the form of ionic (right) and NP (left) from food container into food simulant $\left(4 \%\right.$ acetic acid, $\left.5{ }^{\circ} \mathrm{C}, 40^{\circ} \mathrm{C}\right)$. Reprinted with permission from [86]. Copyright 2016 Taylor \& Francis. (D) The effect of temperature on the amount of migration of AgNPs from polyethylene composite films into a food simulant. Reprinted with permission from [122]. Copyright 2017 Elsevier. 
Temperature has shown its impact on the migration rate, and the normal temperature proved the minimum migration of CuNPs [100]. It was reported that the migration of AgNPs from plastic packaging was enhanced when the temperature was changed from 60 to $95{ }^{\circ} \mathrm{C}$ in the cases. It was also reported that a significant difference in migration rate was observed at the temperatures of 5 and $40{ }^{\circ} \mathrm{C}$, especially during the first $30 \mathrm{~min}$ (Figure 5C) [86]. It was reported that the effect of temperature on migration is sensitive especially when the NP contents vary. Zhu et al. reported that temperature enhancement increase the amount of migration [100], while based on the research by Lin, when the temperature rose from 40 to $70{ }^{\circ} \mathrm{C}$, the amount of migration decreased from 600 to $450\left(\mathrm{ng} / \mathrm{dm}^{2}\right)$ (Figure 5D). It was also reported that the thickness of the food packaging alters the rate of migration [122]. Based on this contradiction, it can be hypothesized that depending on the type of the film/coating and other packaging sources, due to different temperature stabilities, the migration behavior of NPs may be different towards temperature changes.

Considering the discussion above, NP migration (M) from food packaging into food texture is in relationship with various parameters including the type of NP ( ${ }^{\mathrm{T}}$ ), NP concentration $\left(\mathrm{C}_{\mathrm{NP}}\right)$, temperature $(\mathrm{T}), \mathrm{pH}\left({ }^{\mathrm{T}}\right)$, type of packaging material $(\Gamma)$, time $(\mathrm{t})$, the thickness of film layer $(\delta)$, and type of food $(\lambda)$. To sum up, the following equation (Equation (3)) is recommended as a general viewpoint of NP migration from FPS into foods:

$$
M=f\left(T, C_{N P}, T, P, \Gamma, \lambda, t, \delta\right)
$$

By controlling and optimizing these parameters, there is a chance to remove the negative effect of these parameters and decrease the level of migration.

\section{Conclusions}

The addition of metal NPs such as copper and silver has recently received attention due to their good antimicrobial and physicochemical properties. The use of NPs has improved the issues that bionanopolymers have been facing for years, namely fragility, gas barrier properties, and toxic nature. Among the various particles, nano-copper and silver play a major role due to their low price, higher antimicrobial properties, and simple equipment.

It is therefore important to monitor and measure the potential for NP release under conditions that noticeably change the surface area of the food packaging. However, NP-based food packaging not only can improve the shelf life of food and prevent microorganisms growth but also can be hazardous to human life. Therefore, it is recommended that scientists consider migration tests during their research.

However, due to the toxic nature of NPs and their toxicity, which may cause disease and toxicity to humans, more studies need to be done on their migration. It is reasonable to assume that after nanoparticles migrate from packaging to food and are then consumed by the consumer, these nanoparticles may accumulate and adversely affect human health. Scientifically, Fick's law of diffusion applies to the migration of the most organic components from plastics into foods or simulants. This migration phenomenon comprises two phases: firstly, the release of $\mathrm{Ag} / \mathrm{CuNPs}$ from the surface, and secondly, the oxidative dissolution of $\mathrm{Ag} / \mathrm{Cu}$. The rate and amount of migration of AgNPs and CuNPs depend on the time, temperature, food simulants, type of film/coating, $\mathrm{pH}$, and film thickness. NP migration evaluation entails more experiments and validation, and more experiments along with each other are recommended.

Funding: This research received no external funding.

Institutional Review Board Statement: Not applicable.

Informed Consent Statement: Not applicable.

Data Availability Statement: The data presented in this study are available on request from the corresponding author. 
Acknowledgments: This research did not receive any specific grant from funding agencies in the public, commercial, or not-for-profit sectors.

Conflicts of Interest: The author has declared no conflict of interest.

\section{References}

1. Robertson, G.L. Food Packaging. In Encyclopedia of Agriculture and Food Systems; Van Alfen, N.K., Ed.; Academic Press: Oxford, UK, 2014; pp. 232-249.

2. Becerril, R.; Nerín, C.; Silva, F. Encapsulation systems for antimicrobial food packaging components: An update. Molecules 2020, 25, 1134. [CrossRef]

3. Castro-Rosas, J.; Ferreira-Grosso, C.R.; Gómez-Aldapa, C.A.; Rangel-Vargas, E.; Rodríguez-Marín, M.L.; Guzmán-Ortiz, F.A.; Falfan-Cortes, R.N. Recent advances in microencapsulation of natural sources of antimicrobial compounds used in food-A review. Food Res. Int. 2017, 102, 575-587. [CrossRef]

4. Ribeiro-Santos, R.; Andrade, M.; Sanches-Silva, A. Application of encapsulated essential oils as antimicrobial agents in food packaging. Curr. Opin. Food Sci. 2017, 14, 78-84. [CrossRef]

5. Rehman, A.; Jafari, S.M.; Aadil, R.M.; Assadpour, E.; Randhawa, M.A.; Mahmood, S. Development of active food packaging via incorporation of biopolymeric nanocarriers containing essential oils. Trends Food Sci. Technol. 2020, 101, 106-121. [CrossRef]

6. Atarés, L.; Chiralt, A. Essential oils as additives in biodegradable films and coatings for active food packaging. Trends Food Sci. Technol. 2016, 48, 51-62. [CrossRef]

7. Lin, D.; Yang, Y.; Wang, J.; Yan, W.; Wu, Z.; Chen, H.; Zhang, Q.; Wu, D.; Qin, W.; Tu, Z. Preparation and characterization of $\mathrm{TiO}_{2}$-Ag loaded fish gelatin-chitosan antibacterial composite film for food packaging. Int. J. Biol. Macromol. 2020, 154, 123-133. [CrossRef]

8. Arfat, Y.A.; Ejaz, M.; Jacob, H.; Ahmed, J. Deciphering the potential of guar gum/Ag-Cu nanocomposite films as an active food packaging material. Carbohydr. Polym. 2017, 157, 65-71. [CrossRef] [PubMed]

9. Garcia, C.V.; Shin, G.H.; Kim, J.T. Metal oxide-based nanocomposites in food packaging: Applications, migration, and regulations. Trends Food Sci. Technol. 2018, 82, 21-31. [CrossRef]

10. Chowdhury, S.; Teoh, Y.L.; Ong, K.M.; Zaidi, N.S.R.; Mah, S.-K. Poly(vinyl) alcohol crosslinked composite packaging film containing gold nanoparticles on shelf life extension of banana. Food Packag. Shelf Life 2020, 24, 100463. [CrossRef]

11. Peighambardoust, S.J.; Pournasir, N.; Pakdel, P.M. Properties of active starch-based films incorporating a combination of Ag, ZnO and $\mathrm{CuO}$ nanoparticles for potential use in food packaging applications. Food Packag. Shelf Life 2019, 22, 100420. [CrossRef]

12. Lomate, G.B.; Dandi, B.; Mishra, S. Development of antimicrobial LDPE/Cu nanocomposite food packaging film for extended shelf life of peda. Food Packag. Shelf Life 2018, 16, 211-219. [CrossRef]

13. Riahi, Z.; Priyadarshi, R.; Rhim, J.-W.; Bagheri, R. Gelatin-based functional films integrated with grapefruit seed extract and TiO2 for active food packaging applications. Food Hydrocoll. 2021, 112, 106314. [CrossRef]

14. Al-Tayyar, N.A.; Youssef, A.M.; Al-Hindi, R.R. Antimicrobial packaging efficiency of $\mathrm{ZnO}-\mathrm{SiO}_{2}$ nanocomposites infused into PVA/CS film for enhancing the shelf life of food products. Food Packag. Shelf Life 2020, 25, 100523. [CrossRef]

15. Wang, Y.; Cen, C.; Chen, J.; Fu, L. MgO/carboxymethyl chitosan nanocomposite improves thermal stability, waterproof and antibacterial performance for food packaging. Carbohydr. Polym. 2020, 236, 116078. [CrossRef] [PubMed]

16. Hoseinnejad, M.; Jafari, S.M.; Katouzian, I. Inorganic and metal nanoparticles and their antimicrobial activity in food packaging applications. Crit. Rev. Microbiol. 2018, 44, 161-181. [CrossRef]

17. Attaran, S.A.; Hassan, A.; Wahit, M.U. Materials for food packaging applications based on bio-based polymer nanocomposites:A review. J. Thermoplast. Compos. Mater. 2017, 30, 143-173. [CrossRef]

18. Perinelli, D.R.; Fagioli, L.; Campana, R.; Lam, J.K.; Baffone, W.; Palmieri, G.F.; Casettari, L.; Bonacucina, G. Chitosan-based nanosystems and their exploited antimicrobial activity. Eur. J. Pharm. Sci. 2018, 117, 8-20. [CrossRef]

19. Torres-Giner, S.; Wilkanowicz, S.; Melendez-Rodriguez, B.; Lagaron, J.M. Nanoencapsulation of Aloe vera in synthetic and naturally occurring polymers by electrohydrodynamic processing of interest in food technology and bioactive packaging. J. Agric. Food Chem. 2017, 65, 4439-4448. [CrossRef] [PubMed]

20. Yu, B.; Leung, K.M.; Guo, Q.; Lau, W.M.; Yang, J. Synthesis of Ag- $\mathrm{TiO}_{2}$ composite nano thin film for antimicrobial application. Nanotechnology 2011, 22, 115603. [CrossRef]

21. Li, W.-R.; Xie, X.-B.; Shi, Q.-S.; Zeng, H.-Y.; Ou-Yang, Y.-S.; Chen, Y.-B. Antibacterial activity and mechanism of silver nanoparticles on Escherichia coli. Appl. Microbiol. Biotechnol. 2010, 85, 1115-1122. [CrossRef] [PubMed]

22. Hu, T.L.; Hwa, J.Z.; Chang, W.F.; Wu, J. Anti-bacterial study using nano silver-doped high density polyethylene pipe. Sustain. Environ. Res. 2012, 22, 153-158.

23. Dutta, R.; Nenavathu, B.P.; Gangishetty, M.K.; Reddy, A. Studies on antibacterial activity of ZnO nanoparticles by ROS induced lipid peroxidation. Colloids Surfaces B Biointerfaces 2012, 94, 143-150. [CrossRef]

24. Saravanakumar, K.; Sathiyaseelan, A.; Mariadoss, A.V.A.; Xiaowen, H.; Wang, M.-H. Physical and bioactivities of biopolymeric films incorporated with cellulose, sodium alginate and copper oxide nanoparticles for food packaging application. Int. J. Biol. Macromol. 2020, 153, 207-214. [CrossRef] [PubMed]

25. Draskovic, N.; Temperley, J.; Pavicic, J. Comparative perception(s) of consumer goods packaging: Croatian consumers perspective(s). Int. J. Manag. Cases 2009, 11, 154-163. [CrossRef] 
26. Carbone, M.; Donia, D.T.; Sabbatella, G.; Antiochia, R. Silver nanoparticles in polymeric matrices for fresh food packaging. J. King Saud Univ. Sci. 2016, 28, 273-279. [CrossRef]

27. Kowsalya, E.; MosaChristas, K.; Balashanmugam, P.; Rani, J.C. Biocompatible silver nanoparticles/poly(vinyl alcohol) electrospun nanofibers for potential antimicrobial food packaging applications. Food Packag. Shelf Life 2019, 21, 100379. [CrossRef]

28. Yu, Z.; Wang, W.; Kong, F.; Lin, M.; Mustapha, A. Cellulose nanofibril/silver nanoparticle composite as an active food packaging system and its toxicity to human colon cells. Int. J. Biol. Macromol. 2019, 129, 887-894. [CrossRef] [PubMed]

29. Mastromatteo, M.; Conte, A.; Lucera, A.; Saccotelli, M.A.; Buonocore, G.G.; Zambrini, A.V.; Del Nobile, M.A. Packaging solutions to prolong the shelf life of Fiordilatte cheese: Bio-based nanocomposite coating and modified atmosphere packaging. LWT 2015, 60, 230-237. [CrossRef]

30. Li, F.; Liu, Y.; Cao, Y.; Zhang, Y.; Zhe, T.; Guo, Z.; Sun, X.; Wang, Q.; Wang, L. Copper sulfide nanoparticle-carrageenan films for packaging application. Food Hydrocoll. 2020, 109, 106094. [CrossRef]

31. Almasi, H.; Jafarzadeh, P.; Mehryar, L. Fabrication of novel nanohybrids by impregnation of CuO nanoparticles into bacterial cellulose and chitosan nanofibers: Characterization, antimicrobial and release properties. Carbohydr. Polym. 2018, 186, 273-281. [CrossRef]

32. Martínez-Abad, A.; Lagaron, J.M.; Ocio, M.J. Development and characterization of silver-based antimicrobial ethylene-vinyl alcohol copolymer (EVOH) films for food-packaging applications. J. Agric. Food Chem. 2012, 60, 5350-5359. [CrossRef]

33. Vermeiren, L.; Devlieghere, F.; Debevere, J. Effectiveness of some recent antimicrobial packaging concepts. Food Addit. Contam. 2002, 19, 163-171. [CrossRef]

34. Rai, M.; Yadav, A.; Gade, A. Silver nanoparticles as a new generation of antimicrobials. Biotechnol. Adv. 2009, 27, 76-83. [CrossRef]

35. Hamed, A.; Rahimi, N.; Dastmalchi, F.; Soltani, M.; Jafar, R.; Neda, K.; Mansour, F. The effects of nanosilver (nanocid ${ }^{\circledR}$ ) on survival percentage of rainbow trout (Oncorhynchus Mykiss). Pak. J. Nutr. 2009, 8, 1178-1179.

36. Mirzajani, F.; Ghassempour, A.; Aliahmadi, A.; Esmaeili, M.A. Antibacterial effect of silver nanoparticles on Staphylococcus aureus. Res. Microbiol. 2011, 162, 542-549. [CrossRef]

37. Toker, R.; Kayaman-Apohan, N.; Kahraman, M. UV-curable nano-silver containing polyurethane based organic-inorganic hybrid coatings. Prog. Org. Coat. 2013, 76, 1243-1250. [CrossRef]

38. Barani, S.; Ahari, H.; Bazgir, S. Increasing the shelf life of pikeperch (Sander lucioperca) fillets affected by low-density polyethylene $/ \mathrm{Ag} / \mathrm{TiO}_{2}$ nanocomposites experimentally produced by sol-gel and melt-mixing methods. Int. J. Food Prop. 2018, 21, 1923-1936. [CrossRef]

39. Moadab, S.; Ahari, H.; Shahbazzadeh, D.; Motalebi, A.A.; Anvar, A.A.; Rahmania, J.; Shokrgozar, M.R. Toxicity study of nanosilver (nanocid ${ }^{\circledR}$ ) on osteoblast cancer cell line. Int. Nano Lett. (INL) 2011, 1, 11-16.

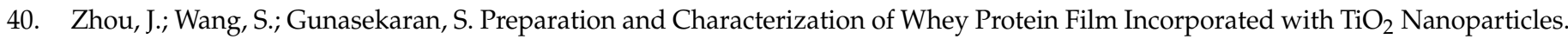
J. Food Sci. 2009, 74, N50-N56. [CrossRef]

41. Lin, D.; Huang, Y.; Liu, Y.; Luo, T.; Xing, B.; Yang, Y.; Yang, Z.; Wu, Z.; Chen, H.; Zhang, Q.; et al. Physico-mechanical and structural characteristics of starch/polyvinyl alcohol/nano-titania photocatalytic antimicrobial composite films. LWT 2018, 96, 704-712. [CrossRef]

42. Ahari, H.; Karim, G.; Anvar, A.A.; Pooyamanesh, M.; Sajadis, A.; Mostaghim, A.; Heydari, S. Synthesis of the silver nanoparticle by chemical reduction method and preparation of nanocomposite based on agnps. In Proceedings of the 4th World Congress on Mechanical, Chemical, and Material Engineering, Madrid, Spain, 16-18 August 2018.

43. Kakoolaki, S.; Ahari, H.; Anvar, A.A.; Yadolahi, M. Influence of Ag/LDPE nanocomposite film coating on quality of Huso huso fillet during refrigerated storage. Food Health 2019, 2. [CrossRef]

44. Sarwar, M.S.; Niazi, M.B.K.; Jahan, Z.; Ahmad, T.; Hussain, A. Preparation and characterization of PVA/nanocellulose/Ag nanocomposite films for antimicrobial food packaging. Carbohydr. Polym. 2018, 184, 453-464. [CrossRef]

45. Wu, Z.; Huang, X.; Li, Y.-C.; Xiao, H.; Wang, X. Novel chitosan films with laponite immobilized Ag nanoparticles for active food packaging. Carbohydr. Polym. 2018, 199, 210-218. [CrossRef] [PubMed]

46. Cao, C.; Wang, Y.; Zheng, S.; Zhang, J.; Li, W.; Li, B.; Guo, R.; Yu, J. Poly (butylene adipate-co-terephthalate)/titanium dioxide/silver composite biofilms for food packaging application. LWT 2020, 132, 109874. [CrossRef]

47. Lotfi, S.; Ahari, H.; Sahraeyan, R. The effect of silver nanocomposite packaging based on melt mixing and sol-gel methods on shelf life extension of fresh chicken stored at $4{ }^{\circ} \mathrm{C}$. J. Food Saf. 2019, 39, e12625. [CrossRef]

48. Li, B.; Ma, J.; Wang, D.; Liu, X.; Li, H.; Zhou, L.; Liang, C.; Wang, H. Self-adjusting antibacterial properties of Ag-incorporated nanotubes on micro-nanostructured Ti surfaces. Biomater. Sci. 2019, 7, 4075-4087. [CrossRef]

49. Deng, J.; Ding, Q.M.; Li, W.; Wang, J.H.; Liu, D.M.; Zeng, X.X.; Liu, X.Y.; Ma, L.; Deng, Y.; Su, W.; et al. Preparation of Nano-SilverContaining Polyethylene Composite Film and Ag Ion Migration into Food-Simulants. J. Nanosci. Nanotechnol. 2020, 20, 1613-1621. [CrossRef] [PubMed]

50. Zawadzka, K.; Kądzioła, K.; Felczak, A.; Wrońska, N.; Piwoński, I.; Kisielewska, A.; Lisowska, K. Surface area or diameter-Which factor really determines the antibacterial activity of silver nanoparticles grown on $\mathrm{TiO}_{2}$ coatings? New J. Chem. 2014, 38, 3275-3281. [CrossRef]

51. Bikiaris, D.N.; Triantafyllidis, K.S. HDPE/Cu-nanofiber nanocomposites with enhanced antibacterial and oxygen barrier properties appropriate for food packaging applications. Mater. Lett. 2013, 93, 1-4. [CrossRef] 
52. Llorens, A.; Lloret, E.; Picouet, P.; Fernandez, A. Study of the antifungal potential of novel cellulose/copper composites as absorbent materials for fruit juices. Int. J. Food Microbiol. 2012, 158, 113-119. [CrossRef]

53. Grigoriadou, I.; Paraskevopoulos, K.; Karavasili, M.; Karagiannis, G.; Vasileiou, A.; Bikiaris, D. HDPE/Cu-nanofiber nanocomposites with enhanced mechanical and UV stability properties. Compos. Part. B Eng. 2013, 55, 407-420. [CrossRef]

54. Bruna, J.E.; Peñaloza, A.; Guarda, A.; Rodríguez, F.; Galotto, M.J. Development of $\mathrm{MtCu}^{2+} / \mathrm{LDPE}$ nanocomposites with antimicrobial activity for potential use in food packaging. Appl. Clay Sci. 2012, 58, 79-87. [CrossRef]

55. Cárdenas, G.; Díaz, V.J.; Meléndrez, M.F.; Cruzat, C.C.; García Cancino, A. Colloidal Cu nanoparticles/chitosan composite film obtained by microwave heating for food package applications. Polym. Bull. 2009, 62, 511-524. [CrossRef]

56. Santo, C.E.; Taudte, N.; Nies, D.H.; Grass, G. Contribution of Copper Ion Resistance to Survival of Escherichia coli on Metallic Copper Surfaces. Appl. Environ. Microbiol. 2007, 74, 977-986. [CrossRef] [PubMed]

57. Komeily-Nia, Z.; Montazer, M.; Latifi, M. Synthesis of nano copper/nylon composite using ascorbic acid and CTAB. Colloids Surfaces A Physicochem. Eng. Asp. 2013, 439, 167-175. [CrossRef]

58. Cushen, M.; Kerry, J.; Morris, M.; Cruz-Romero, M.; Cummins, E. Evaluation and simulation of silver and copper nanoparticle migration from polyethylene nanocomposites to food and an associated exposure assessment. J. Agric. Food Chem. 2014, 62, 1403-1411. [CrossRef]

59. Anvar, A.; Haghighat Kajavi, S.; Ahari, H.; Sharifan, A.; Motallebi, A.; Kakoolaki, S.; Paidari, S. Evaluation of the antibacterial effects of $\mathrm{Ag}-\mathrm{TIO}_{2}$ nanoparticles and optimization of its migration to sturgeon caviar (Beluga). Iran. J. Fish. Sci. 2019, 18, 954-967.

60. Choi, J.I.; Chae, S.J.; Kim, J.M.; Choi, J.C.; Park, S.J.; Choi, H.J.; Bae, H.; Park, H.J. Potential silver nanoparticles migration from commercially available polymeric baby products into food simulants. Food Addit. Contam. Part. A 2018, 35, 996-1005. [CrossRef]

61. de Azeredo, H.M. Antimicrobial nanostructures in food packaging. Trends Food Sci. Technol. 2013, 30, 56-69. [CrossRef]

62. Bott, J.; Störmer, A.; Franz, R. A model study into the migration potential of nanoparticles from plastics nanocomposites for food contact. Food Packag. Shelf Life 2014, 2, 73-80. [CrossRef]

63. Proestos, C.; Pasias, I.N.; Papageorgiou, V.; Barmperis, K.; Thomaidis, N.S. Trace Elements: Effect on Tomato Plant and on Human Health after Consumption of Tomato Fruit and Tomato Fruit Food Products, Tomatoes: Cultivation, Varieties and Nutrition; Nova Science Publishers Inc.: New York, NY, USA, 2013; pp. 275-288.

64. Amiridou, D.; Voutsa, D. Alkylphenols and phthalates in bottled waters. J. Hazard. Mater. 2011, 185, 281-286. [CrossRef]

65. Grombe, R. Method and Apparatus for Analysis of Engineered NPs Distribution in a Substrate. 2011. Available online: https:/ / patentscope2.wipo.int/search/en/detail.jsf?docId=WO2011121447\&tab=PCTBIBLIO (accessed on 20 March 2021).

66. Pilot, R.; Signorini, R.; Durante, C.; Orian, L.; Bhamidipati, M.; Fabris, L. A review on surface-enhanced raman scattering. Biosensors 2019, 9, 57. [CrossRef]

67. Tang, H.; Zhu, C.; Meng, G.; Wu, N. Review—Surface-enhanced raman scattering sensors for food safety and environmental monitoring. J. Electrochem. Soc. 2018, 165, B3098-B3118. [CrossRef]

68. Picó, Y. Chapter 9-Safety assessment and migration tests. In Nanomaterials for Food Packaging; Cerqueira, M.Â.P.R., Lagaron, J.M., Pastrana Castro, L.M., de Oliveira Soares Vicente, A.A.M., Eds.; Elsevier: Amsterdam, The Netherlands, 2018; pp. $249-275$.

69. Santos, É.J.D.; Oliveira, F.M.P.; Herrmann, A.B.; Sturgeon, R.E. ICP OES determination of contaminant elements leached from food packaging films. Braz. Arch. Biol. Technol. 2017, 60. [CrossRef]

70. Koo, J.H. Polymer Nanocomposites; McGraw-Hill Professional Pub.: New York, NY, USA, 2006.

71. Liu, J.-F.; Yu, S.-J.; Yin, Y.-G.; Chao, J.-B. Methods for separation, identification, characterization and quantification of silver nanoparticles. TrAC Trends Anal. Chem. 2012, 33, 95-106. [CrossRef]

72. Störmer, A.; Bott, J.; Kemmer, D.; Franz, R. Critical review of the migration potential of nanoparticles in food contact plastics. Trends Food Sci. Technol. 2017, 63, 39-50. [CrossRef]

73. Song, H.; Li, B.; Lin, Q.-B.; Wu, H.-J.; Chen, Y. Migration of silver from nanosilver-polyethylene composite packaging into food simulants. Food Addit. Contam. Part. A 2011, 28, 1-5. [CrossRef] [PubMed]

74. Stehrer, T.; Heitz, J.; Pedarnig, J.D.; Huber, N.; Aeschlimann, B.; Günther, D.; Scherndl, H.; Linsmeyer, T.; Wolfmeir, H.; Arenholz, E. LA-ICP-MS analysis of waste polymer materials. Anal. Bioanal. Chem. 2010, 398, 415-424. [CrossRef] [PubMed]

75. Pasias, I.; Raptopoulou, K.; Proestos, C. Migration from Metal Packaging into Food. Ref. Modul. Food Sci. 2018. [CrossRef]

76. Alderton, D. X-Ray Diffraction (XRD), Reference Module in Earth Systems and Environmental Sciences; Elsevier: Amsterdam, The Netherlands, 2020.

77. Zimbone, M.; Calcagno, L.; Messina, G.C.; Baeri, P.; Compagnini, G. Dynamic light scattering and UV-vis spectroscopy of gold nanoparticles solution. Mater. Lett. 2011, 65, 2906-2909. [CrossRef]

78. Hou, J.; Ci, H.; Wang, P.; Wang, C.; Lv, B.; Miao, L.; You, G. Nanoparticle tracking analysis versus dynamic light scattering: Case study on the effect of $\mathrm{Ca}^{2+}$ and alginate on the aggregation of cerium oxide nanoparticles. J. Hazard. Mater. 2018, 360, 319-328. [CrossRef]

79. Hosseini, R.; Ahari, H.; Mahasti, P.; Paidari, S. Measuring the migration of silver from silver nanocomposite polyethylene packaging based on $\left(\mathrm{TiO}_{2}\right)$ into Penaeus semisulcatus using titration comparison with migration methods. Fish. Sci. 2017, 83, 649-659. [CrossRef]

80. Dutta, P.K.; Nagy, A.; Harrison, A.; Sabbani, S.; Munson, J.R.S.; Waldman, W.J. Silver nanoparticles embedded in zeolite membranes: Release of silver ions and mechanism of antibacterial action. Int. J. Nanomed. 2011, 6, 1833-1852. [CrossRef] 
81. Metak, A.M.; Nabhani, F.; Connolly, S.N. Migration of engineered nanoparticles from packaging into food products. LWT 2015, 64, 781-787. [CrossRef]

82. Marchiore, N.G.; Manso, I.J.; Kaufmann, K.C.; Lemes, G.F.; Pizolli, A.P.D.O.; Droval, A.A.; Bracht, L.; Gonçalves, O.H.; Leimann, F.V. Migration evaluation of silver nanoparticles from antimicrobial edible coating to sausages. LWT 2017, 76, 203-208. [CrossRef]

83. Wyser, Y.; Adams, M.; Avella, M.; Carlander, D.; Garcia, L.; Pieper, G.; Rennen, M.; Schuermans, J.; Weiss, J. Outlook and challenges of nanotechnologies for food packaging. Packag. Technol. Sci. 2016, 29, 615-648. [CrossRef]

84. Lloret, E.; Picouet, P.; Fernández, A. Matrix effects on the antimicrobial capacity of silver based nanocomposite absorbing materials. LWT-Food Sci. Technol. 2012, 49, 333-338. [CrossRef]

85. Liu, F.; Huai-Ning, Z.; Zhao, Q.; Shi, Y.-J.; Zhong, H.-N. Migration of copper from nanocopper/LDPE composite films. Food Addit. Contam. Part A 2016, 33, 1741-1749. [CrossRef] [PubMed]

86. Ozaki, A.; Kishi, E.; Ooshima, T.; Hase, A.; Kawamura, Y. Contents of Ag and other metals in food-contact plastics with nanosilver or Ag ion and their migration into food simulants. Food Addit. Contam. Part A 2016, 33, 1490-1498. [CrossRef] [PubMed]

87. Zamindar, N.; Anari, E.S.; Bathaei, S.S.; Shirani, N.; Tabatabaei, L.; Mahdavi-Asl, N.; Khalili, A.; Paidari, S. Application of copper nano particles in antimicrobial packaging: A mini review. Acta Sci. Nutr. Heal. 2020, 4, 14-18. [CrossRef]

88. Echegoyen, Y.; Rodríguez, S.; Nerín, C. Nanoclay migration from food packaging materials. Food Addit. Contam. Part A 2016, 33, 530-539. [CrossRef] [PubMed]

89. Lin, Q.-B.; Li, H.; Zhong, H.-N.; Zhao, Q.; Xiao, D.-H.; Wang, Z.-W. Migration of Ti from nano-TiO 2 -polyethylene composite packaging into food simulants. Food Addit. Contam. Part A 2014, 31, 1284-1290. [CrossRef] [PubMed]

90. Cushen, M.; Kerry, J.; Morris, M.; Cruz-Romero, M.; Cummins, E. Silver migration from nanosilver and a commercially available zeolite filler polyethylene composites to food simulants. Food Addit. Contam. Part A 2014, 31, 1132-1140. [CrossRef] [PubMed]

91. Echegoyen, Y.; Nerín, C. Nanoparticle release from nano-silver antimicrobial food containers. Food Chem. Toxicol. 2013, 62, 16-22. [CrossRef]

92. Bott, J.; Störmer, A.; Franz, R. A.; Franz, R. A comprehensive study into the migration potential of nano silver particles from food contact polyolefins, chemistry of food, food supplements, and food contact materials: From production to plate. In ACS Symposium Series; American Chemical Society (ACS): District of Columbia, WA, USA, 2014; pp. 51-70.

93. Jokar, M.; Rahman, R.A. Study of silver ion migration from melt-blended and layered-deposited silver polyethylene nanocomposite into food simulants and apple juice. Food Addit. Contam. Part A 2014, 31, 734-742. [CrossRef]

94. Cushen, M.; Kerry, J.; Morris, M.; Cruz-Romero, M.; Cummins, E. Migration and exposure assessment of silver from a PVC nanocomposite. Food Chem. 2013, 139, 389-397. [CrossRef]

95. Ntim, S.A.; Thomas, T.A.; Begley, T.H.; Noonan, G.O. Characterisation and potential migration of silver nanoparticles from commercially available polymeric food contact materials. Food Addit. Contam. Part A 2015, 32, 1003-1011. [CrossRef] [PubMed]

96. Mozhayeva, D.; Engelhard, C. Separation of silver nanoparticles with different coatings by capillary electrophoresis coupled to icp-ms in single particle mode. Anal. Chem. 2017, 89, 9767-9774. [CrossRef]

97. Trbojevich, R.A.; Khare, S.; Lim, J.-H.; Watanabe, F.; Gokulan, K.; Krohmaly, K.; Williams, K. Assessment of silver release and biocidal capacity from silver nanocomposite food packaging materials. Food Chem. Toxicol. 2020, 145, 111728. [CrossRef]

98. Liu, J.; Hurt, R.H. Ion release kinetics and particle persistence in aqueous nano-silver colloids. Environ. Sci. Technol. 2010, 44, 2169-2175. [CrossRef]

99. Hannon, J.C.; Kerry, J.P.; Cruz-Romero, M.; Azlin-Hasim, S.; Morris, M.; Cummins, E. Human exposure assessment of silver and copper migrating from an antimicrobial nanocoated packaging material into an acidic food simulant. Food Chem. Toxicol. 2016, 95, 128-136. [CrossRef] [PubMed]

100. Jiang, Z.-W.; Yu, W.-W.; Li, Y.; Zhu, L.; Hu, C.-Y. Migration of copper from nanocopper/polypropylene composite films and its functional property. Food Packag. Shelf Life 2019, 22, 100416. [CrossRef]

101. Asgher, M.; Qamar, S.A.; Bilal, M.; Iqbal, H.M. Bio-based active food packaging materials: Sustainable alternative to conventional petrochemical-based packaging materials. Food Res. Int. 2020, 137, 109625. [CrossRef] [PubMed]

102. Campardelli, R.; Della Porta, G.; Gomez, V.; Irusta, S.; Reverchon, E.; Santamaria, J. Encapsulation of titanium dioxide nanoparticles in PLA microspheres using supercritical emulsion extraction to produce bactericidal nanocomposites. J. Nanopart. Res. 2013, 15, 1987. [CrossRef]

103. Polat, S.; Fenercioglu, H.; Turhan, E.U.; Guclu, M. Effects of nanoparticle ratio on structural, migration properties of polypropylene films and preservation quality of lemon juice. J. Food Process. Preserv. 2017, 42, e13541. [CrossRef]

104. Kechek'Yan, P.A.; Bazhenov, S.L.; Kechek'Yan, A.S. The influence of biaxial orientation on the mechanical properties of polyethylene filled with zno nanoparticles. Polym. Sci. Ser. A 2018, 60, 373-380. [CrossRef]

105. Zhang, J.; Wang, X.; Lu, L.; Li, D.; Yang, X. Preparation and performance of high-impact polystyrene $(\mathrm{HIPS}) / \mathrm{nano}^{-T i O_{2}}$ nanocomposites. J. Appl. Polym. Sci. 2003, 87, 381-385. [CrossRef]

106. Rane, A.V.; Kanny, K.; Abitha, V.K.; Thomas, S. Chapter 5-Methods for synthesis of nanoparticles and fabrication of nanocomposites. In Synthesis of Inorganic Nanomaterials; Mohan Bhagyaraj, S., Oluwafemi, O.S., Kalarikkal, N., Thomas, S., Eds.; Woodhead Publishing: Cambridge, UK, 2018; pp. 121-139.

107. Mihaly Cozmuta, A.; Peter, A.; Mihaly Cozmuta, L.; Nicula, C.; Crisan, L.; Baia, L.; Turila, A. Active packaging system based on $\mathrm{Ag} / \mathrm{TIO}_{2}$ nanocomposite used for extending the shelf life of bread. Chemical and microbiological investigations. Packag. Technol. Sci. 2015, 28, 271-284. [CrossRef] 
108. Ahari, H.; Barani, S.; Bazgir, S. Nanocomposites produced by sol-gel and melt mixing methods. In Proceedings of the 4th World Congress on Mechanical, Chemical, and Material Engineering, Madrid, Spain, 16-18 August 2018.

109. Pandey, V.K.; Upadhyay, S.N.; Niranjan, K.; Mishra, P.K. Antimicrobial biodegradable chitosan-based composite Nano-layers for food packaging. Int. J. Biol. Macromol. 2020, 157, 212-219. [CrossRef]

110. Najwa, I.N.A.; Yusoff, M.M.; Hanani, Z.N. Potential of silver-kaolin in gelatin composite films as active food packaging materials. Food Packag. Shelf Life 2020, 26, 100564. [CrossRef]

111. Emamifar, A.; Kadivar, M.; Shahedi, M.; Solimanian-Zad, S. Effect of nanocomposite packaging containing Ag and ZnO on reducing pasteurization temperature of orange juice. J. Food Process. Preserv. 2011, 36, 104-112. [CrossRef]

112. Chi, H.; Song, S.; Luo, M.; Zhang, C.; Li, W.; Li, L.; Qin, Y. Effect of PLA nanocomposite films containing bergamot essential oil, $\mathrm{TiO}_{2}$ nanoparticles, and Ag nanoparticles on shelf life of mangoes. Sci. Hortic. 2019, 249, 192-198. [CrossRef]

113. Huang, Y.; Chen, S.; Bing, X.; Gao, C.; Wang, T.; Yuan, B. Nanosilver migrated into food-simulating solutions from commercially available food fresh containers. Packag. Technol. Sci. 2011, 24, 291-297. [CrossRef]

114. Li, W.; Li, L.; Zhang, H.; Yuan, M.; Qin, Y. Evaluation of PLA nanocomposite films on physicochemical and microbiological properties of refrigerated cottage cheese: LI et al. J. Food Process. Preserv. 2017, 42, e13362. [CrossRef]

115. Kim, M.H.; Kim, T.-H.; Ko, J.A.; Ko, S.; Oh, J.-M.; Park, H.J. Kinetic and thermodynamic studies of silver migration from nanocomposites. J. Food Eng. 2019, 243, 1-8. [CrossRef]

116. Tavakoli, H.; Rastegar, H.; Taherian, M.; Samadi, M.; Rostami, H. The effect of nano-silver packaging in increasing the shelf life of nuts: An in vitro model. Ital. J. Food Saf. 2017, 6, 6874. [CrossRef]

117. Beigmohammadi, F.; Peighambardoust, S.H.; Hesari, J.; Azadmard-Damirchi, S.; Khosrowshahi, N.K. Antibacterial properties of LDPE nanocomposite films in packaging of UF cheese. LWT 2016, 65, 106-111. [CrossRef]

118. Arvanitoyannis, I.S.; Kotsanopoulos, K.V. Migration phenomenon in food packaging. Food-package interactions, mechanisms, types of migrants, testing and relative legislation-A review. Food Bioprocess. Technol. 2014, 7, 21-36. [CrossRef]

119. McClements, D.J.; Xiao, H. Is nano safe in foods? Establishing the factors impacting the gastrointestinal fate and toxicity of organic and inorganic food-grade nanoparticles. NPJ Sci. Food 2017, 1, 1-13. [CrossRef] [PubMed]

120. Mourdikoudis, S.; Pallares, R.M.; Thanh, N.T.K. Characterization techniques for nanoparticles: Comparison and complementarity upon studying nanoparticle properties. Nanoscale 2018, 10, 12871-12934. [CrossRef] [PubMed]

121. Xin, Y.; Zhang, N.; YananLv, N.Z.; Wang, J.; Li, Q.; Zhang, Z. From nanoparticles to single atoms for Pt/CeO 2 : Synthetic strategies, characterizations and applications. J. Rare Earths 2020, 38, 850-862. [CrossRef]

122. Wu, L.-B.; Su, Q.-Z.; Lin, Q.-B.; Peng, W.-D.; Chen, C.-F.; Wang, Z.-W.; Hu, C.-Y. Impact of migration test method on the release of silver from nanosilver-polyethylene composite films into an acidic food simulant. Food Packag. Shelf Life 2017, $14,83-87$. [CrossRef]

123. Li, Y. Migration of metals from ceramic food contact materials. 1: Effects of $\mathrm{pH}$, temperature, food simulant, contact duration and repeated-use. Food Packag. Shelf Life 2020, 24, 100493. [CrossRef]

124. Yang, C.; Zhu, B.; Wang, J.; Qin, Y. Structural changes and nano-TiO 2 migration of poly(lactic acid)-based food packaging film contacting with ethanol as food simulant. Int. J. Biol. Macromol. 2019, 139, 85-93. [CrossRef] [PubMed]

125. Hauri, J.F.; Niece, B.K. Leaching of silver from silver-impregnated food storage containers. J. Chem. Educ. 2011, 88, 1407-1409. [CrossRef]

126. Von Goetz, N.; Fabricius, L.; Glaus, R.; Weitbrecht, V.; Günther, D.; Hungerbühler, K. Migration of silver from commercial plastic food containers and implications for consumer exposure assessment. Food Addit. Contam. Part A 2013, 30, 612-620. [CrossRef] [PubMed] 